\title{
Değişen Güvenlik Anlayışının Uluslararası Örgüt Örnekleri Üzerinden Analiz Edilmesi
}

\author{
Analyzing Changing Security Concept \\ through Samples of International Organizations
}

\author{
Özlem ÖZKÖSEDAĞ İÇIN*
}

$\ddot{0}$.

Soğuk Savaş yilları boyunca ve sonrasında koşullarda, sistemde ve algılamalarda beliren değişiklikler, güvenlik anlayışının farklılaşmasına neden olmuşsur. Güvenlik anlayışında meydana gelen değışim, uluslararast örgütlerin yapisal yenilenmeye gitmelerine, güvenlik strateji belgelerini yeni koşullara uygun olacak şekilde düzenlemelerine yol açmışıtr. Uluslararast örgütlerdeki yenilenme, teoride ve pratikte kendini gösteren güvenlik alanindaki zihniyet farklllaşmasinin somut delillerindendir. Çallşmada, ilk olarak güvenlik kavraminın ifade ettikleri incelenecek, ardindan geleneksel ve yeni güvenlik anlaylşı arasindaki farklllıklar Soğuk Savaş dönemi ve sonrasinn koşullarn göz önünde bulundurularak açıklanacaktır. Güvenlik anlaylşının geçirdiği değişim, NATO ve BM örnekleri üzerinden somutlaştırlarak analiz edilecektir. Bu bağlamda çallşmanın amacı, geleneksel güvenlik yaklaşımın benimseyenlerin iddia ettiklerinin aksine güvenlik anlayışının geri dönüş olmayacak şekilde değiştiğini göstermek ve bu değişimin sadece düşünce dünyasında varlık göstermediğini, uygulama itibari ile de somıç doğurduğumu vurgulamaktır.

Anahtar Kelimeler: Güvenlik, Yeni Güvenlik Anlayışı, Uluslararası Örgütler, NATO, BM.

\footnotetext{
Uludağ Üniversitesi, Sosyal Bilimler Enstitüsü, Uluslararası İlişkiler Bölümü Doktora Oğrencisi, e-posta: ozlemozkosedag@ hotmail.com.
}

99

Güvenlik Stratejileri

Y11: 13

Sayl: 25 


\section{Özlem ÖZKÖSEDAĞ İÇIN}

\section{Abstract}

The resulting changes in the system, in the conditions and in the perception during and after the Cold War years, have caused the differentiation of the security concept. Changes occurring in the security concept have led to the structural revision of international organizations and the regulation of security strategy documents in accordance with the new condition. Revision in international organizations is one of the tangible proofs which manifests itself differentiation mentality on theory and practice in the field of security. With this study, the expression of the concept of security will be primarily examined, and then the differences between the traditional and the new security concept will be described in consideration of Cold War era and post-conditions. The transformation of the security concept will be analyzed by solidifying over the examples of NATO and the UN. In this context, the purpose of the study is, to show that security concept has changed and there is no going back unlike it was claimed by the adopters of the traditional security approach. This transformation shows itself not only in the world of ideas, but it also generates results in practice.

Key Words: Security, New Security Concept, International Organization, NATO, UN.

\section{Giriş}

Güvenlik, realist kuramcılar tarafindan varlık sorunuyla ilintili bir kavram olarak değerlendirilmektedir. Uluslararası ilişkiler disiplini çerçevesinde, değişen koşullara bağl olarak uluslararası örgütler ve hatta bireyler, devletlerin yanı sıra sistemin yeni aktörleri arasında sayılmıştır. Dolayısıyla bütün aktörlerin varlığının bekası güvenliğin kapsamı içine girmiştir. Böylece, güvenliğin kapsamı genişlemiş ve Soğuk Savaş sonrası koşullar dikkate alınarak yeni güvenlik anlayışları gündeme getirilmiştir.

Yeni güvenlik anlayışı, var olan güvenlik durumuna ilişkin daha kabul edilebilir açıklamalar yapan, teorik altyapısı farklı disiplinlerden gelen akademisyenler tarafindan inşa edilmiş yeni perspektifleri anlatabilmek için kullanılır. Aynı zamanda, güvenliğin farklı boyutları olduğunu belirtir ve güvenlik söz konusu olduğunda bireyi merkeze 
Değișen Güvenlik Anlayıșının

Uluslararası Örgüt Örnekleri Üzerinden Analiz Edilmesi

yerleştirir. Bu kapsamda yeni güvenlik anlayışının ürünü olan insan güvenliği anlayışı, güvenlik alanında, devletlerin tartışmasız üstünlüklerinin ve devletin ulusal güvenliğinin bireylerin güvenliğinden önce geldiği ön kabulünün sorgulanmaya başlandığını gösterir.

Yeni güvenlik anlayışı çerçevesinde, devletler, otonom hareket edebilen bağımsız aktörler olmaktan ziyade, kendisiyle birlikte diğer sistem aktörlerinin ve çevrenin güvenliğini düşünerek politika belirlemesi gereken aktörler olarak kabul edilirler. Soğuk Savaş sonrası dönemde devletlerin hareket alanı yeni aktörler ve değişen sistem koşulları tarafindan daraltılmıştır.

Yeni dönemin aktörleri arasında zikredilen uluslararası örgütlenmeler, küreselleşme ve farklı alanlarda yaşanılan karşıllklı bağıml11ık ilişkileri göz önünde bulundurulduğunda sistemdeki etkililik oranlarını yükseltmiştir. Aldıklanı kararlarla, güvenlik anlayışımın değiştiğini kanıtlayan uygulamalara imza atmaktadırlar. Çalışmada geçirdiği değişim inceleme altına alınan örgütler Kuzey Atlantik Antlaşmas1 Örgütü (NATO) ve Birleşmiş Milletler'dir (BM). Bilindiği gibi NATO, İkinci Dünya Savaşı'nın ardından Batı Bloğu'nun ortak savunma şemsiyesi olarak kurgulanmış ve günün güvenlik anlayışına uygun olarak ulus devletlerin askerî güvenliğinin sağlanması amacına hizmet etmiștir. Sovyet Bloğu'nun muhtemel saldırılarının caydırılmasında vazife üstlenen NATO, örgüt üyesi devletlerin sınırlarının korunmasını amaçlamıștır. BM, NATO ile karşılaştırıldığında farklı amaçlara hizmet etmek için kurulmuş olmasına ve daha geniş bir değerler sistemini karşılamasına rağmen, Soğuk Savaş son bulana dek özellikle ilgilendiği alan, devletler ve onların öncelikli sorunları olmuştur. Güvenlik anlayışının çerçevesini ise 1990'lı yıllarda uluslararası sistemde köklü değişimler yaşanmaya başlanınca genişletmiştir. Geleneksel güvenlik anlayışının egemen olduğu dönemde kurulan ve mevcut anlayışa uygun olarak tasarlanan bu iki örgüt, yeni dönemin koşullarında yaşanılan değişime ayak uydurarak kendini yenilemiştir. Kendilerinde gerekli değişiklikleri yapmış olmaları, bu dönüşüm sayesinde sistem dışına atılmadan sistem içinde yerlerini muhafaza etmiş olmaları, bahsi geçen örgütlerin çalışmaya dâhil edilmelerine neden olmuştur.

NATO, Soğuk Savaş sonrası yeni güvenlik anlayışına uyum 


\section{Özlem ÖZKÖSEDAĞ IÇCiN}

sağlayarak Yeni Strateji Konseptleri belirlemiş, kurumsal yapısında değişikliğe gitmiştir. Güvenliği tehdit eden asimetrik tehditlerin var olduğunu ve bu tehditlerle mücadele edebilmek için devletler ve örgütlenmelerle gerçekleştirilecek iş birliklerinin gerekli olduğunu belirtmiştir. Çünkü tehditler sınır aşan niteliktedir, devletler ve örgütler tek başlarına yeni tehditlere mücadele edemeyeceklerdir. Yine NATO Strateji Konseptleri incelendiğinde güvenliğin farklı alanlarına vurgu yapıldığ görülmektedir. BM ise insan güvenliği anlayışının önemi üzerinde durmuş, güvenliğin farklı alanlarda tehdit edildiğini belirtmiştir. Soğuk Savaş sonrası dönemde BM düzenlemelerinde, ortaya çıkan yeni tehditlerin öncelikle bireylerin güvenliğini tehdit ettiği bildirilirken, çevresel ve ekonomik sorunların artan önemine vurgu yapılmıştır. BM yeni ajanslar kurarak ve programlar oluşturarak kurumsal yapısını yeni dönem güvenlik sorunları ile başa çıkabilmek için yenilemiştir.

Çalışmada öncelikle güvenlik kavramının anlamı üzerinde durulacak, ardından Soğuk Savaş sonrası yaşanılan değişim ve koşullar göz önünde bulundurularak yeni güvenlik anlayışı açıklanacaktır. Son olarak NATO ve BM'nin geçirdiği değişim anlatılarak güvenlik anlayışındaki zihniyet farklılaşmasının izleri takip edilecektir.

102

Security Strategies

Year: 13

Issue: 25
2. Güvenliğin Anlamı, Soğuk Savaş Yılları ve Sonrasında Koşullarda Yaşanan Değişim ile Güvenlik Anlayışları

Varlık sorunu çerçevesinde değerlendirildiğinde insanlık tarihi kadar derin kökleri olan güvenlik, risk ve tehdit kavramlarıla yakından ilgilidir. ${ }^{1}$ Uluslararası İlişkiler kapsamında güvenlik ve politika arasındaki bağ İkinci Dünya Savaşı sonrasında kurulmuştur. Amerika Birleşik Devletleri (ABD) tarafindan 1947'de düzenlenen Ulusal Güvenlik Şurası/Konseyi sonunda, güvenliğin de bir ulusal politika alanı olduğu tespit edilirken, diğer ulus devletler de bu tespite katılmıştır. ${ }^{2}$

${ }^{1}$ Fikret Birdişli, Soğuk Savaş Sonrası Dönemde Güvenlik Alanında Yaşanan Son Gelişmeler Ile Birlikte Teori ve Pratikte Uluslararası Güvenlik. Kavram, Teori, Uygulama, Seçkin, Ankara Ocak 2014, s. 13.

2 Bertel Heurlin and Kristian Kristensen, "International Security", International 
Değișen Güvenlik Anlayıșının

Uluslararası Örgüt Örnekleri Üzerinden Analiz Edilmesi

Güvenliğin ortak tanımının yapılması mümkün olmamıştır. Güvenlik, genel olarak tehdit ve tehlikeden uzak olma hali olarak açıklanırken; Wolfers'ın tanımlamasında tehdidin kazanılmış değerlere yönelik olması ayrıca vurgulanmıştır. Başka bir deyişle, değerlere yönelmiş bir tehdidin varlığ durumunda da "mutlak güvensizlik" yaşanacaktır. ${ }^{3}$ Devletler için, elde ettikleri ve elinde bulundurdukları her türlü somut ve soyut değere yönelik tehdidin olmaması önemlidir. Ancak bu durumda devletler kendilerini güvende hissedecektir. ${ }^{4}$ Ullman'a göre ise, güvenlik, uğruna başka şeylerden vazgeçmeyi gerekli kılan bir olguyken, değeri kaybedilince veya tehdit edilince anlaşılmaktadır. ${ }^{5}$ Aktöre ve konuya göre güvenliğin tanımı ve çerçevesi değişmektedir. Baldwin, "Kim için güvenlik?" ve "Hangi değerler için?" soruları sorularak güvenliğin daha rahat tanımlanabileceğini vurgular. Baldwin'e göre, "Ne kadar güvenlik?", "Hangi tehditlere karşı?", "Hangi araçlarla?", "Ne pahasına ve hangi zaman dilimi içerisinde?" gibi sorular güvenlik tanımlamaları yapılırken çerçeveyi netleştirmek için kullanılmalıdır. ${ }^{6}$

Güvenlik, uluslararası ilişkiler kapsamında yapılan çalışmalarda dönemlere ayrılarak ve bu dönemlerin koşulları göz önünde bulundurularak anlamlandırılmış ve kategorize edilmiştir. Soğuk Savaş döneminin görece istikrarlı yapısı, ulus devletlerin güvenliği anlayışı olarak açıklanabilecek geleneksel güvenlik anlayışının olgunlaşmasına neden olurken nükleer yarışta dengeye gelinmesi, silahlanmanın ürkütücü boyutlara ulaşması, fikirsel anlamda daha liberal söylemlerin güç kazanmaya başlaması neticesinde mevcut durumun sürdürülebilir olmadığı ifade edilmeye başlanmıştır. Soğuk Savaș yıllarındaki güvenlik anlayıșını şekillendiren tehdit algılaması neticesinde oluşan bloklu yapının son bulması,

Relations, Vol. 2, p. 4.

${ }^{3}$ Arnold Wolfers, "National Security: As an Ambiguous Symbol", Political Science Quarterly, Vol. 67, No. 4, December 1952, pp. 484-485.

${ }^{4}$ Wolfers, a.g.m, p. 484.

${ }^{5}$ Richard H. Ullman, "Redefining Security", International Security, Vol. 8, No. 1, Summer, 1983, p. 133.

${ }^{6}$ David A. Baldwin, "The Concept of Security", Review of International Studies, 1997, pp. 13-16.

103

Güvenlik Stratejileri

Y11: 13

Sayı: 25 


\section{Özlem ÖZKÖSEDAĞ IÇCiN}

kutupların çekim etkisinin bitmesiyle güvenliğin alanı genişlemiş; güvenlik, farklı boyutlarıyla ele alınmaya başlanmıştır. $\mathrm{Bu}$ değişimin gerçekleşmesini sağlayan ve çeşitli boyutlarda cereyan eden farklılaşma öncelikle sistem üzerinde kendini göstermiştir.

Soğuk Savaşın 1990'da son bulması ve iki bloklu yapının nihayete ermesiyle, ABD dünya liderliği iddiasında bulunmuş, ${ }^{7}$ sistem şekil değiștirmiş, örümcek ağına benzeyen bir șekle bürünmüștür. Yeni dönemde, Burton ve Haas'ın çalışmalarında uluslararası örgütler, karar vericiler ve liderler sisteme dâhil olan aktörler olarak tanımlanmıştır. ${ }^{8}$ Küreselleşme ulaşım ve iletişim imkânlarını artırmış; ulusal ve uluslararası kamuoyları etkili aktörler olarak sisteme eklenmiştir. Küreselleşme sayesinde iç-dış ayrımı muğlâklaşmış, böylece karar vericiler kararlarını verirken daha fazla etkeni hesap etmek durumunda kalmıștır. Küresel ekonomik bağlantıların kurulması karşılıklı bağımlılık ilişkisinin gerçekleşmesine neden olmuştur. Held'e göre, küreselleşme sonucunda tüm bu yaşanılanlar, ulus-devlet mantığına dayalı yapıyı sorunlu hâle getirmiştir. ${ }^{9}$ Burton'a göre, yeni dönemde egemen devletlerarası ilişkiler, var olan çok boyut ve taraflı ilişkileri açıklamak

Security Strategies

Year: 13

Issue: 25 konusunda yetersiz kalmıştır. ${ }^{10} 1990$ sonrasında, sistemin yeni oyuncuları olan sivil toplum kuruluşları, hükümet dış1 kuruluşlar, ulus-ötesi oluşumlar, ulus devlet dünyasına ait güvenlik meselelerinde yeri geldiğinde birey haklarının koruyuculuğunu yapmaktadır. ${ }^{11}$ Yeni dönem,

${ }^{7}$ Zbigniew Brezezinski, Büyük Satranç Tahtası, Amerika'nın Küresel Üstünlüğ̈̈ ve Bunun Jeostratejik Gereklilikleri, çev. Yelda Türedi, İnkılâp Kitapevi, İstanbul, 2005, ss. 41-43.

${ }^{8}$ Tayyar Arı, Uluslararası İlişkiler Teorileri. Çatışma. Hegemonya, İşbirliği, Alfa, Bursa, 2002, ss. 297-300.

9 David Held, Democracy and the Global Order From the Modern State to Cosmopoliten Governance, Polity Press, 1995, pp. 89-98.

${ }^{10}$ John W. Burton, "International Relations or World Society", Paul R. Viotti and Mark V. Kauppi (ed.), Theory: Realism, Pluralism, Globalism, 2. ed., Macmillan Publishing Co., pp. 375-377.

${ }^{11}$ İbrahim S. Canbolat, Uluslararası İlişkilerde Türkiye Savaş ve Barış Arasında Dünya, 4.Bask1, Aktüel, Kasım 2012, ss. 185-187. 
Değișen Güvenlik Anlayıșının

Uluslararası Örgüt Örnekleri Üzerinden Analiz Edilmesi

yeni güvenlik tehditlerini beraberinde getirmiştir. Mikro milliyetçilik temelli etnik grup çatışmaları, salgın hastalıklar, suç örgütleri, AİDS, terör, gidaların yapısında meydana gelen bozulmalar, kıtlık, iklim değişiklikleri, ekonomik kriz ve başarısızlıklar, göçmen ve göç sorunu, temel kaynakların kirlenmesi ve çevre sorunları, başanısız devlet yönetimleri yeni dönemde karşılaşılan tehditlerden sadece bazılarıdır. Bu tehditlerin kurbanları bireyler, toplumlar, küresel anlamda bütün varlıklar olmaktadır. Yeni tehditler dünya ve üzerindeki yaşamı fiziken yok oluşa götürebilecek kadar tehlikeli sonuçların doğmasına neden olabilecek boyuttadır. ${ }^{12}$ Tehditler o kadar artmıştır ki, alınan önlemlere rağmen güvenliğin tam olarak sağlanması devletler ve bireyler için ulaşılabilir bir hedef olmaktan uzaktır. ${ }^{13}$ Üstelik bu tehditler 11 Eylül terör saldırılarının gösterdiği gibi öngörülememektedir, bu da saldırının neden olacağı yıkıma dair duyulan korkuyu artırmaktadır.

Soğuk Savaş sonrasında insanlara ve ulus devletlere yönelmiş tehditlerin birçoğu artık başka devletlerin ordularından gelmemektedir. Herhangi bir devlet orijinli olmayan tehditler ve daha ciddisi bir devletin kendi içinde vatandaşlarına uyguladığı şiddet Soğuk Savaş sonrasında yaşanılan çatışmaların esas sebebi olarak görülmektedir. ${ }^{14}$ İnsan ölümlerine neden olan çatışmaların büyü̈k çoğunluğu etnik temelli iç savaşlar ve terör eylemleri sonunda gerçekleşmiştir. $\mathrm{Bu}$ dönemde devletlerarası çatışmaların yaşanılan bütün çatışmalar içindeki payı $\% 10$ olarak tespit edilmektedir. Devletlerin güven içinde olması, her zaman vatandaşlarının da güven içinde yaşıyor olması anlamına gelmemektedir. ${ }^{15}$ Ulus devletlerin rejimlerine yönelik tehditlerin pek çoğu yine iç tehdit mahiyetinde zuhur etmektedir. Hükümetler kendi ordularının

\footnotetext{
${ }^{12}$ Heurlin and Kristensen, a.g.m., p. 3.

${ }^{13}$ Evren Balta Paker, Küresel Güvenlik Kompleksi. Uluslararası Siyaset ve Güvenlik, Birinci Baskı, İletişim, 2012, İstanbul, ss. 121-129.

${ }^{14}$ Benjamin Miller, "The Concept of Security: Should It Be Redefined?", Journal of Strategic Studies, Vol. 24, Issue 2, 2001, p. 19.

${ }^{15}$ Human Security Report 2005, daha fazla bilgi için bkz. http://www.hsrgroup.org/ human-security-reports/2005/text.aspx, Erișim Tarihi: 02.01.2015.
}

Güvenlik Stratejileri

Y11: 13

Sayl: 25 


\section{Özlem ÖZKÖSEDAĞ IC̣îN}

müdahaleleriyle görevden uzaklaşmak zorunda kalmaktadır. İnsan hakları ihlalleri, etnik ve dini temelli çatışmalar, ekonomik başarısızlıklar gibi sorunlar devletlerin içyapılarında tehlikeli istikrarsılılı dönemlerinin yaşanmasına neden olmaktadır. İç çatışmalar, kitlesel göç hareketlerini tetiklemekte; neticede devletlerarası çatışmalar yaşanabilmektedir. ${ }^{16}$

Tüm bu değişiklikler güvenlik anlayıșını değiștirirken, yapılan güvenlik çalışmalarının içeriğini de belirlemektedir. Güvenlik konulu çalışmalar içerikleri itibariyle geleneksel olanlar ve yenilikçi anlayışla yapılmış olanlar olarak temelde ikiye ayrılabilmektedir. Bu ayrımı yapabilmek, çalışmalara yön veren teorik açıklama zeminlerinin katkısıyla mümkün olmaktadır. Klasik realist ve neo-realist yaklaşımların savunuları geleneksel anlayışı açıklamak için kullanılırken; eleștirel güvenlik yaklaşımı, feminist güvenlik çalışmaları, insan güvenliği anlayışı yeni yaklaşımlar konusunda çalışma yapılırken dayanak noktası olmaktadır. Çalışmanın bu kısmında geleneksel ve yeni güvenlik anlayışları, çeşitli uluslararası ilişkiler teorilerinin açıklayıcı güçlerinden de faydalanılarak incelenecektir.

106

Security Strategies

Year: 13

Issue: 25

\subsection{Geleneksel Güvenlik Anlayısısı}

Geleneksel güvenlik anlayışının temelleri modern ulus devletler ortaya çıkmadan önce atılmış; 17'nci yüzyıl hanedan ulus devletlerinden itibaren var olan iç güvenlik-dış güvenlik ayrımı neticesinde şekillenmiştir. ${ }^{17}$ Geleneksel güvenlik anlayışı temelde devletlerin dış güvenliği üzerine eğilir. Amaç, devletlerin sınırlarının güvenliğinin tesis edilmesi ve varlığının devam ettirilmesinin sağlanmasıdır. Bu bağlamda, geleneksel yaklaşımlar, daha çok güvenliğin askerî ve siyasi boyutuyla ilgilenmektedir. Ulus devletin esas gündemi ulusal güvenliktir. Devletin bekası, vatandaşlarının da varlıklarını devam ettirmesi anlamına gelecektir. Geleneksel güvenlik anlayışının realist retoriğinde güvenliği

${ }^{16}$ Ken Booth, "Security and Emancipation", Rewiev of International Studies, Vol. 17, No. 4, Oct. 1991, pp. 313-326, p. 318.

${ }^{17}$ Hans Günter Brauch, "Güvenliğin Yeniden Kavramsallaştırılması: Barış, Güvenlik, Kalkınma ve Çevre Kavramsal Dörtlüsü", Uluslararası Illişkiler, Cilt 5, Sayı 18, Yaz 2008, s. 3. 
Değișen Güvenlik Anlayıșının

Uluslararası Örgüt Örnekleri Üzerinden Analiz Edilmesi

sağlayan devlet olmadan vatandaşların yaşamlarının zorlaşacağı inancı vardır. ${ }^{18} \mathrm{Bu}$ nedenle, devlet güvenlik halinin inşasından sorumlu tutulmuşstur.

Geleneksel güvenlik anlayışı çerçevesinde yapılan ilk güvenlik çalışmaları realist perspektifle oluşturulmuştur. Realizmin kuram olarak güvenlik alanına hâkim olması ise İkinci Dünya Savaşı sonrasında başlayan Soğuk Savaş yıllarında gerçekleşmiştir. Yapılan çalışmaların mahiyetlerine bakılınca bu tespit yapılmaktadır. ${ }^{19} \mathrm{Bu}$ dönemde yapılan çalışmalar, ulus devletin askerî güvenliği üzerine odaklanmıştır. Güç ve egemenlik alanının dokunulmazlığ ve ulusal sınırların dokunulmazlığı, güvenlik çalışmalarının temel konuları olmuştur. Soğuk Savaş boyunca ulusal ve uluslararası güvenlik, Sovyet Sosyalist Cumhuriyetler Birliği (SSCB) ve ABD rekabeti çerçevesinde ele alınmıştır. İki kutuplu dünya sistemi, güvenlik çalışmalarının içeriğini de belirlemiştir. Kutuplaşmanın etkisiyle tüm dünyadaki güvenlik çalışmaları ideolojik, ekonomik ve askerî rekabetin gölgesinde yapılmıştır. ${ }^{20}$ Geleneksel güvenlik anlayışında devletler en etkili aktör olarak kabul edildiğinden, devletlerin iç işlerine müdahale etmeme bir prensip haline getirilmiştir. İkinci Dünya Savaşı sonrasında kurulan BM'nin müktesebatında da bu anlayış yer bulmuștur. ${ }^{21}$

Çalışmada geleneksel güvenlik anlayışı realist teorinin açılamalarıyla ortaya konulurken, belirtilmelidir ki realist teori kendi içinde farklı anlayışları barındırmaktadır. Realist teori, klasik realizm, neo-realizm/yapisal realizm ve neo-klasik realizm olarak ayrıştırılabilecekken, her birinin vardığı sonuçlar ve nedenleri farklı olsa

Güvenlik Stratejileri

Y11: 13

Sayı: 25

18 Mustafa Aydın, "Uluslararası İlişkilerin "Gerçekçi”" Teorisi: Kökeni, Kapsamı, Kritiğì", Uluslararası İlişkiler, Cilt 1, Sayı 1, Bahar, 2004, s. 42.

${ }^{19}$ Ken Booth, "Security and Self: Reflections of a Fallen Realist ", Keith Krause and Micheal C. Williams (ed.), Critical Security Studies. Concepts and Cases, UCL Press, UK, 1997, ss. 94-95.

${ }^{20}$ David Mutimer, "Reimagining Security: The Metophors of Proliferation ", Keith Karuse and Michael C. Williams (ed.), Critical Security Studies: Concepts and Cases, UCL Press, UK, 1997, p. 187.

${ }^{21}$ H. Tarık Oğuzlu, "Dünya Düzenleri ve Güvenlik: Ulus-Devlet Güvenlik Anlayışı Aşılıyor mu?", Güvenlik Stratejileri Dergisi, Sayı 06, 2007, s. 7. 


\section{Özlem ÖZKÖSEDAĞ IÇCiN}

dahi, güvenlik üzerine düşünceleri incelendiğinde, aktör olarak devleti ele almaları, güvenliği en önemli politika alanlarından biri olarak tanımlamaları ve öncelikli olarak ulus devletlerin güvenliğine odaklanmaları itibariyle bir uyum sergilemektedirler. Bu nedenle, açıklamalar yapılırken farklı bakış açılarına has değerlendirmelerde, akımın hangi kolundan bahsedildiği açıkça belirtilecektir. Ortak noktalarda ise realist yaklaşım tanımlaması tercih edilecektir. Bu üç temel realist anlayış arasındaki farklardan biri, güvenliğin nasıl sağlanacağıyla ilgilidir. Güvenliği ve uluslararası ilişkileri belirleyen etken klasik realistlere göre insanın yapısı, neo-realistlere göre devletler sisteminin yapısı ve neo-klasiklere göre devletin yapısıdır. ${ }^{22}$

Klasik realistler, insanın, doğası itibariyle kusurlu olduğunu belirtir. Bu nedenle hırs ve çıkarlarını gerçekleştirmeye çalışan insan güç peşinde koşacaktır. Dolayısıyla, sistem anarşik bir yapı arz edecektir. "Uluslararası sistemde güç mücadelesi esastır" şeklinde sıralanabilecek, Morgenthau tarafindan geliştirilen ve siyasal realizmin temel savlarından olan bu savlar klasik realist düşüncenin temelini oluşturur. ${ }^{23}$ Morgenthau, realizmin temel kaynaklarından biri olarak kabul edilen eserinde yer aldığı şekliyle, siyasal realizmi var olanı daha iyi anlamak için geliştirilen bir teori olarak değerlendirir ve geleneksel güvenlik anlayışının önemli konularından biri olan güç konusunun üzerinde durur. Ona göre, güç bireylerin ve devletlerin birbirleri üzerinde kurdukları kontroldür. Çıkarlar ise güç çerçevesinde belirlenir. Güç açısından tanımlanan çıkar konsepti sayesinde politikanın konusuna mantıksal bir düzen getirilmiş olur. Böylelikle politika teorik olarak anlaşılabilir bir hâl alır. Çıkarlar dış politikanın yönetilmesi ve değerlendirilmesi sırasında başvurulan temel standartlardır; fakat çıkarlar ve ulus devlet arasındaki ilişki tarihi akış esnasında kurulmuştur, zaman içinde çıkarlar değişebilir. Devletler varlık mücadelesi verir ve onlar için varlık sorunları bütün moral

${ }^{22}$ Eyüp Ersoy, "Realizm", Ramazan Gözen (der.) Uluslararası İlişkiler Teorileri, 1. Baskı, İletişim Yayınları, İstanbul, 2014, s. 166.

${ }^{23}$ Hans J. Morgenthau, Politics Among Nations, The Struggle For Power and Peace, MC Graw Hill Higher Education, Seventh Edution, pp. 3-16. 
Değișen Güvenlik Anlayıșının

Uluslararası Örgüt Örnekleri Üzerinden Analiz Edilmesi

değerlerin üstünde yer alır. Siyasal realizmde devletler rasyonel varlıklar olarak kabul edilir. Her devlet çıkarlarına uygun şekilde hareket edecektir. Çıkarlarına ulaşabilmek için de gücünü artırmak isteyecektir. Her devlet çıkarlarına ulaşmak için güç artırmak isteyeceğinden sistem anarşiktir. $\mathrm{Bu}$ yapıda devletler kendi güvenliğinden sorumludur. İş birlikleri ya işlevsizdir ya da geçicidir. Uluslararası iş birlikleri sadece güvenliğin sağlanması için yapılan tercihler neticesinde gerçekleştirilir. Öncelikli tercih, devletlerin askerî kapasitelerini artırarak güvenliği tesis etmesidir. Bu rasyonel bir tercih olacaktır. ${ }^{24}$ Ancak mümkün değil ise iş birliğine gidilecektir. İş birlikleri de örgütler sayesinde gerçekleştirilebilecektir. Ancak genel olarak realistler, uluslararası ilişkilerde uluslararası örgütlerin fonksiyonu, hukukun yeri ve etkinliği konularında iyimser olmayan bir yaklaşım sergilemektedir. ${ }^{25}$ Kenneth $\mathrm{N}$. Waltz'a göre, devletler, uluslararası sistemde diğer aktörlerle iş birliği gerçekleştirerek ekonomik anlamda kazanç elde edeceklerini bilseler dahi, iş birliği konusunda çekimser davranacaktır. Bunun nedeni ise sistemin anarşik yapısının devletlerin davranışlarını belirlemesidir. Ulusal güvenlik konularını, askerî perspektiften değerlendirme geleneğine sahip olan devletler, sistemden kaynaklanan riskleri göz önünde bulundurarak iş birliğine gitmemeyi tercih edecektir. ${ }^{26}$ Devletler maksimum güvenliğe ulaşmak için tehditlerin tamamen ortadan kaldırılmasını sağlayacak stratejiler belirleyecektir. ${ }^{27}$ Şu da belirtilmelidir ki, realist güvenlik anlayışı tehdidin ortadan kaldırılması için her türlü önlemin alınmasını meşru kabul etmektedir. ${ }^{28}$ Uzun yıllar uluslararası ilişkilere hâkim olan bu teorik algllama ve pratikteki uygulama güvenliğin farklı boyutlarıyla

\footnotetext{
${ }^{24}$ John J. Mearshimer, The Tragedy of Great Power Politics, W. W. Norton, New York, 2001, p. 21.

25 Mustafa Aydın, "Uluslararası İlişkilerde Teori, Yaklaşım ve Analiz", Siyasal Bilgiler Fakültesi Dergisi, Cilt 50, No. 3-4, 1996, s. 93.

${ }^{26}$ Kenneth N. Waltz, "Anarchic Orders and Balances Of Power", Robert O. Keohane (ed.), Neorealism and Its Critics, New York, 1986, Columbia University Press, pp. 100-104.

${ }^{27}$ Oğuzlu, a.g.m., s. 6.

${ }^{28}$ Barry Buzan et. al., Security: A New Framework for Analysis, Lynne Rienner Publishers, London,1998, s. 21.
}

109

Güvenlik Stratejileri

Y11: 13

Sayı: 25 


\section{Özlem ÖZKÖSEDAĞ IC̣îN}

ele alınmasını kısıtlayıcı etki yapmıştır.

Klasik realizmin önemli isimlerinden olan E. H. Carr, İkinci Dünya Savaşı'na giden yolu ve bu süreçte dönemin idealistlerinin hatalarının neler olduğunu belirttiği eserinde, idealist söylemler çerçevesinde bir sistemin inşa edilememiş olmasının sebebi olarak idealist değerlendirmelerin gerçeklerden hareket edilmeden yapılmış olmasını gösterir. Ona göre, sistemin realist değerlendirmesi yapının ne olması gerektiğiyle değil, nasıl olduğuyla ilgilenmelidir. İdealistlerin hatası yapıy1 tanımadan ideal bir yap1 önermeleriydi; bu da ütopik bir yaklaşımdı. ${ }^{29}$ Güç, siyasal düzenlerin mecburi bileşenidir. Her devlet güçlü olmak ve güçlü olduğu ölçüde kontrolü elinde bulundurmak ister. Diğer devletler de güçclü olana kontrol etme yetkisini verme eğilimindedir. ${ }^{30}$ Devletler ulusal güvenliklerini sağlamak için güç artırmayı tercih edecektir. Bu da güç mücadelelerini ve savaşları kaçınılmaz yapacaktır. Güç ve güvenlik, ayrılmaz iki unsur olarak değerlendirilir. Güç aynı zamanda vazgeçilemeyecek bir yönetim aracı olarak kabul edilir. ${ }^{31}$ Ancak güç mücadelesinin esas olduğu sistemde, düzenleyici görev üstlenecek hukuk kurallarının gerekli olduğunu da ret edilmez. İdealist ütopyacılar ve realistler, arasında görüş farklı1ıkları olmasına rağmen, özellikle uluslararası hukuk kurallarını üstlendikleri fonksiyonlar açısından önemser. Hukukun ihtiyacın bir ürünü olduğunu ve idealistlerin Milletler Cemiyeti'ni (MC) oluştururken, amaçlarının sistemde düzeni sağlayacak ve oluşturulan kuralların uygulanmasını takip edecek mekanizma ihtiyacının karşılanması olduğunu belirtir. Realistlerin ise hukuku güçlüler kulübünün bir aracı olarak değerlendirdiğini belirtir. Bu bağlamda, idealistler hukukla ahlakı ilişkilendirirken, gerçekçiler güç ile hukuku bağdaştırmaktadır. ${ }^{32}$ Carr idealistlerin uluslararası hukukun oluşturulmasında gösterdikleri çabayı ve katkıyı takdir etmektedir.

${ }^{29}$ E. H. Carr, Yirmi Yll Krizi 1919-1939, Can Cemgil (çev.), 2. Baskı, İstanbul Bilgi Üniversitesi Yayınları, Ekim 2015, ss. 54-59.

${ }^{30}$ Carr, a.g.e., ss. 267-270.

${ }^{31}$ Carr, a.g.e., ss. $147-151$.

${ }^{32}$ Carr, a.g.e., ss. 210-218. 
Değișen Güvenlik Anlayıșının

Uluslararası Örgüt Örnekleri Üzerinden Analiz Edilmesi

Ancak realist düşüncenin genelinde, uluslararası hukukun uluslararası sorunların çözümünde işlevsiz olduğu yönündeki kanaatin var olduğu belirtilmelidir.

Klasik realistler, ulus devletin güvenliğini bireylerin ya da vatandaşların güvenliğinin üstünde görür. Güvenliğin asıl konusu ulus devletin güvenliği ve varlığının devam ettirilmesi olmalıdır. Çünkü bireylerin güvenliğini temin edecek oluşum devlettir. $\mathrm{Bu}$ nedenle, devletin güvenliğinin tesis edilmesi, güvenlik halinin yaşanabilmesi için ön şart olarak kabul edilir. Realizmin klasik dönemin önemli isimlerinden biri olan Hobbes' in tespitiyle, "güvenliği temin eden ve refahın artırılmasını sağlayan devlet olmasa idi vatandaşlarının yaşamı k1sa ve sefil olurdu". 33

Neo-realistler, insan doğasıyla ilgili saptamalara katılmakla birlikte, özellikle sistemin anarşik yapısının mevcut sistemi açıklayacak en önemli etken olduğunu ileri sürer. Anarşik yapı ile kast edilen, sistemde sürekli savaşların yaşanması veya savaş durumunun süreklilik arz etmesi ya da uluslararası hukuk kurallarının yokluğu değildir. Anarşiye sebep olan, küresel düzeyde uluslararası hukuk kurallarının uygulanmasını sağlayacak bir örgütlenmenin olmaması ve uluslararası çatışmaları yönetip engelleyecek etkili küresel bir kurumun bulunmamasıdır. ${ }^{34}$ Uluslararası sistemde etkili olan egemen ulus devletlerin davranışlarını düzenleyecek bir üst otoritenin olmamas1, her devletin kendi güvenlik sorununu kendisinin çözme yoluna gitmesine yol açmaktadır. ${ }^{35} \mathrm{Bu}$ da anarşiye süreklilik kazandırmaktadır. Neo-realistlere göre, anarşik sistemde güvenliğin sağlayıcısı devletin kendisi iken, kazanılmış değerlere yönelik tehdidin olmaması hâli güvenlik hâlidir. Ancak bu, anarşik yapı nedeniyle pek mümkün değildir. Bu durumda, devlet, muhtemel tehdidi makul

33 Thomas Hobbes, Leviathan, der. C. B. Macpherson, Harmondsworth, Penguin, 1986, s. 82.

${ }^{34}$ Jil Steans et. al., Introduction to International Relations Perspectives and Themes, 3rd Edition, Routledge, 2009, s. 57.

${ }^{35}$ John J. Mearsheimer, "Back to the Future: Instability in Europe after the Cold War

“, International Security, Vol. 15, No. 1, Summer 1990, pp. 5-56, p. 12. 


\section{Özlem ÖZKÖSEDAĞ IC̣îN}

maliyetle ortadan kaldırabilecek güç ve kabiliyette olmalıdır. ${ }^{36}$

Realist yaklaşıma göre, uluslararası güvenlik, ulusal güvenlik çerçevesinden incelenebilir. Her iki güvenlikte de, ana aktör ve güvenliği sağlanacak aktör, devlettir. Uluslararası güvenlikten bahsedileceği zaman devletlerarası ilişkilere bakılmalıdır. Fakat Soğuk Savaş sonrası yaptığı çalıșmalarla güvenlik alanında isminden söz ettiren Buzan, uluslararası güvenliği devletlerarası ilişkilerden farklı faktörlerin de etkilediğini düşünmektedir; bunları devletlerin iç politik, ekonomik, toplumsal yapıları ve sosyo-kültürel durumları olarak belirlemektedir. ${ }^{37}$

Geleneksel güvenlik anlayışının temel konularından biri, savaşlardır. ${ }^{38} \mathrm{Bu}$ anlayış için savaşlar kaçınılmazdır. Savaşların yaşanmadığı geçici süre olarak tanımladıkları barış hâli kalıcı değildir. Savaşa yapılan fayda-maliyet analizi sonucunda başvurulmaktadır. Neo-realist Mearsheimer'ın belirttiği gibi, yapılan analiz neticesinde savaș maliyetli olușu ve yararının az oluşu nedeniyle gerçekleşmez ise ancak bu durumda barış hâli yaşanır. ${ }^{39}$ Geleneksel güvenlik anlayışı çerçevesinde yapılan çalışmalar askerî gücün kontrolü, edinilmesi ve kullanımı konuları üzerine odaklanır. Geleneksel olarak adlandırılan ve

Security Strategies

Year: 13

Issue: 25 köken olarak realist bakış açısı ile yapılan çalışmalar, askerî gücü varlığın garantisi olarak görür. ${ }^{40}$ Savaşa hazır olunması ve bu amaçla silahlanmanın, iyi niyete dayalı barış çalışmaları yapmaktan ve silahsızlanmadan daha çok barışa hizmet edeceğine inanırlar. Aksi yönde belirlenecek politikaların dünya gerçeklerine uygun olmayacağın söylerler. ${ }^{41}$ Realistler rasyonel davranış olarak adlandırdıkları kuvvet artırmanın diğer aktörlerin de aynı şekilde davranmasına neden

\footnotetext{
${ }^{36}$ Ayoob, The Third World Security Predicament, aktaran, Miller, a.g.m., p. 16.

${ }^{37}$ Barry Buzan, People, States and Fear: An Agenda for International Security Studies in the Post Cold War Period, Brighton, Harvester Wheatsheaf, 1991, s. 60.

${ }^{38}$ Stephen M. Walt, "The Renaissance of Security Studies", International Studies Quarterly, Vol. 35, No. 2, Jun. 1991, pp. 211-239, p. 212.

${ }^{39}$ Mearsheimer, a.g.m., p. 12.

${ }^{40}$ Steans et. al., a.g.m., p. 64.

${ }^{41}$ Aydin, a.g.m., s. 36.
} 
Değișen Güvenlik Anlayıșının

Uluslararası Örgüt Örnekleri Üzerinden Analiz Edilmesi

olacağını belirtirler. John H. Herz bu durumu güvenlik ikilemi ${ }^{42}$ olarak tanımlar ki, bu kavram realist retoriğin literatüre önemli katkılarından biridir. Sürekli güç biriktirmeyle sonuçlanacak rekabet birbirlerinden ve niyetlerinden emin olmayan aktörler tarafindan gerçekleștirileceği için sürüp gidecektir diyen Herz, güvenlik ikileminin kaçınılmaz olarak oluşacağını vurgular. ${ }^{43}$

Neo-realistlere göre mutlak güvenliğin sağlanması, anarşi nedeniyle mümkün değildir. Dolayısıyla sağlanan güvenlik ancak göreceli güvenlik olacaktır. ${ }^{44}$ Mearsheimer ve Waltz gibi neo-realistler, sistemin anarşik yapısı ile sistem düzeyinde açıklamalar yaparken, anarşik sistemde güç dengesinin sağlanmasının uluslararası güvenlik için kilit önemde olduğunu düşünür. Her ikisi de çalışmalarında farklı sayıda oyuncunun olduğu güç dengesi sistemlerini inceler. Waltz, iki kutuplu güç dengesi sisteminin uluslararası güvenliğin sağlanması için daha faydalı olacağını iddia etmektedir. Çok kutuplu yapının daha çok risk barındıracağını belirtmektedir. $^{45}$

Neo-realist teori, güvenliği, ulus devletlerin temel motivasyon kaynağı olarak görür. Ulus devletler güvenliklerini sağladıktan sonra başka politik hedeflere yönelebilir. Çünkü Waltz’a göre güvenlik varoluşla ilgili bir meseledir. Aynı zamanda neo-realist teoride güvenlik, sıfir toplamlı oyun gibidir. Her devlet güvenliğini artırmaya çalışır fakat bu başkalarının güvenliklerinin tehdit edilmesi veya azalması anlamına gelebilir. $\mathrm{Bu}$ da tek kazananın olduğu sistemin ne kadar sürdürülebilir bir yapı olduğu konusunda sorgulamaların ortaya çıkmasına neden olmuştur.

42 John H. Herz, "Idealist Internationalism and Security Dilemma", World Politics, Cilt. 2, No. 2, 1950, pp. 157-180.

${ }^{43}$ Herz, a.g.m. p. 157.

${ }^{44}$ Buzan, a.g.e., pp. 22-23.

45 Kenneth N. Waltz , "The Origins of War in Neorealist Theory", Journal of Interdisciplinary History, Vol. 18, No. 4, The Origin and Prevention of Major Wars ,Spring 1988 , 615-628, pp. 620-624.

${ }_{46}$ Baldwin, a.g.m., pp. 21-22.

\section{3}

Güvenlik Stratejileri

Y11: 13

Sayı: 25 


\section{Özlem ÖZKÖSEDAĞ IC̣îN}

Realist güvenlik anlayışı, küreselleşme ve Soğuk Savaş'ın bitişi gibi önemli olaylar karşısında teorik açıklama zeminini yeterince güçlendirememiştir. Güvenlik konusundaki indirgemeci yaklaşımı, var olan değişimleri açıklama güçlüğüyle karşılaşmasına neden olmaktadır. Sistemin yanı sıra değișen, çoğalan ve sadece devletten devlete olmayan bu açıdan asimetrik ve tahmin edilemez tehditlere karşı kapsayıcı çözümler önerememektedir. Yine de, 11 Eylül saldırılarından sonra bazı çevreler tarafından geleneksel güvenlik anlayışıyla, reel dünyaya ilişkin en sağlıklı değerlendirmelerin yapıldığg iddia edilmiştir. Güç mücadelesinin ve savaşların esas tehdit olduğu koşulların devam ettiği, bu kapsamda günümüzde de askerî güvenliğin temel güvenlik alanı olarak değerlendirilmesi gerektiği belirtilmiştir. ${ }^{47}$ Geleneksel güvenlik anlayışının ve tezlerinin 11 Eylül saldırılarının ardından tekrar gündeme oturması ve ulusal güvenlik anlayışı ile askerî yöntemlerin hâlâ geçerliliğini koruduğuna yönelik söylemler destek bulurken, ABD'nin Güvenlik Strateji Belgesi'ne de bu anlayış damgasını vurmuştu. ${ }^{48} 2003$ Irak müdahalesi de geleneksel güvenlik anlayışıyla şekillendirilen yeni ABD güvenlik politikasının bir ürünüydü. Ancak müdahale sonucunda, geleneksel güvenlik anlayışı çerçevesinde ve yine geleneksel yöntemler kullanılarak güvenliğin tesis edilemeyeceği anlaşılmıştır.

Balkanlardaki çatışmalar da geleneksel güvenlik anlayışının Strategies tezlerinin Soğuk Savaş sonrası dönemde geçerliliğinin göstergelerinden biri olarak gösterilmiştir. Savaşların güvenliğin temel konusu olmaya devam edeceği ve 21'inci yüzyıllın kanlı bir yüzyıl olacağı belirtilmiştir. ${ }^{49}$ Muhtemel tehlikeye karşı ön alıcı yöntem olarak geleneksel yöntemlerin kullanılması, istenilen sonuçların alınmasını engellemektedir. Ulusal güvenliğin silahlanmayla sağlanabileceği yönündeki geleneksel düşünce

${ }^{47}$ Baylis, a.g.m., s. 71.

48 Felix Sebastian Berenskoetter, "Mapping the Mind Gap: A Comparison of US and European Security Strategies", Security Dialogue, Vol. 36, No. 1, March 2005, pp. 75-90.

${ }^{49}$ Colin S. Gray, "The 21 st Century Security Environment and the Future of War", Parameters ,Winter 2008-2009, p. 17. 
Değișen Güvenlik Anlayıșının

Uluslararası Örgüt Örnekleri Üzerinden Analiz Edilmesi

güvenlik sorunlarının artış göstermesine neden olmaktadır. ${ }^{50}$ Günümüzde BM gibi örgütlerin çalışmaları çerçevesinde şekillenen, 11 Eylül öncesinde var olan ve saldırılar sonrasinda savunulmaya devam edilen yeni güvenlik anlayışı, geleneksel olan bakışa karşı sağlam muhalif yaklaşımlar sergilemeye devam etmektedir.

\subsection{Yeni Güvenlik Anlayıșı}

Soğuk Savaş'ın son bulmasıyla birlikte güvenliğin doğası, en çok düşünülen konulardan biri haline geldi. Yeni dönemde geleceğe iyimser bakanlar, değişimle beraber yeni yüzyılın barışın ve iş birliğinin zamanı olduğunu söyledi. Liberal demokrasi uygulamalarının yaygınlaşması, ulus ötesi kapitalist hareketler, uluslararası örgütlerin faaliyetleri sayesinde iş birliğin artacağını ve barışın yerleşeceğini öne sürdüler. Geleceğe kaygıyla bakanlar ise, anarşinin, etnik milliyetçi hareketler, çatışmalar, kitle imha silahlarının yaygınlaşması sonucunda artacağını düşünüyordu. Var olan güvenlik anlayışının dışına çıkıp yeni koşulları değerlendirenler de güivenliğin değişen tehditler ve yeni güvenlik alanlarını kapsayacak şekilde tekrar tanımlanması gerektiğini ileri sürdü. ${ }^{51}$ İşte bu üçüncü bakış açısı yeni güvenlik anlayışının öncülüğünü yapacak isimleri kapsiyordu. Güvenliğin konusu, kapsamı, aktörleri ve tanımı yeni güvenlik anlayışı çerçevesinde belirlendi. Geleneksel anlayışa ait kabuller, yapılan yeni çalışmalarda dikkate alındı. Devletin sistemin temel aktörü olduğu yeni anlayışın temsilcilerinin pek çoğu tarafindan da kabul edildi. Ancak Soğuk Savaş sonrası dönemde güvenlik anlayışının "yeni" olarak adlandırılması, yeni şartlara ve değişikliklere uygun, daha açıklayıcı güvenlik çalışmalarının yapılmış olmasından kaynaklandı.

Yeni güvenlik anlayışı çerçevesinde yapılan çalışmalar incelendiğinde, güvenliğin kim için inşa edildiği meselesinin sorgulandığı

\footnotetext{
${ }^{50}$ Tayyar Arı, Uluslararası İlişkiler ve Dış Politika, 7. Baskı, MKM Yayınlanı, Bursa, 2008 , s. 585.

${ }^{51}$ Keith Krause and Michael C. Williams, "From Strategy to Security: Foundations of Critical Security Studies", Keith Krause and Michael C. Williams (ed.), Critical Security Studies: Concepts and Cases, UCL Press, UK, 1997, p. 33.
}

\section{5}

Güvenlik Stratejileri

Y11: 13

Sayl: 25 


\section{Özlem ÖZKÖSEDAĞ IÇCiN}

görülür. Martin Shaw da, güvenlik üzerine düşünülürken, öncelikli güvenliği sağlanacak obje üzerinde anlaşılamamış olduğunu bildirir; önceliği insana ya da devlete tanıyan güvenlik çalışmalarının eksik kalacağına inanır. Ona göre, sosyal gruplar ve küresel toplum, yapılan güvenlik çalışmalarına referans olarak dâhil edilmelidir. Güvenliğin tek boyutuyla ele alınması, doğru sonuçlara ulaşılmasını engelleyecektir. Sistemin bütün aktörleri etkileşim içerisinde oldukları diğer aktörlerin güvenlik durumunu etkileyecektir. Bu nedenle farklı aktörler arasındaki ekonomik olmayan; fakat sosyal, kültürel ve değiş̧ik alanlarda kurulan ilişkiler güvenlik çalışmalarında ele alınmalıdır. ${ }^{53}$ Güvenliğgin referans objelerinin bu şekilde çoğalması neticesinde sistemin farklı unsurlarının güvenlikleri yeni güvenlik çalışmalarının konularını oluşturmuşstur.

Yeni güvenlik anlayışı, farklı aktörlerin başka alanlardaki güvenliklerinin yeni tehditler tarafindan tehdit edilmesiyle güvenliğin kapsamının yeni koşullara uygun şekilde yenilenmesi ihtiyacı sonucunda doğmuştur denilebilir. Güvenliğin, devletin güvenliğini merkeze alan geleneksel anlayışa karşı, başka düzeylerdeki güvenlik durumlarını da içerecek şekilde genişletilmesi gerektiğini ilk dile getirenlerden biri de Buzan olmuştur. Buzan'a göre güvenlik, üç düzeyi ve beş ana alanı (sektörü) içerecek şekilde genişletilmelidir. Ulusal güvenliğin yanında birey güvenliği ve uluslararası güvenlik yeni düzeyler olmalıdır. Politik güvenlik, toplumsal güvenlik, ekonomik güvenlik ve çevresel güvenlik de askerî güvenlikle birlikte yeni güvenlik alanları olarak belirlenmelidir. ${ }^{53}$ Buzan, realist yaklaşımdan farklı olarak mevcut tehditlerin sadece devletlerin fiziksel varoluşlarına yönelik olmayabileceğinin altını çizer. Devletlerin, fikirsel, fiziksel ve kurumsal varlıklarının, çevre kaynakl1, toplumsal altyapısı olan, ekonomik, siyasi ve askerî tehditlerin varlığ

${ }^{52}$ Martin Shaw, "There Is No Such Thing as Society": Beyond Individualism and Statism in International Security Studies, Review of International Studies, 19, 1993, ss. 159-175. aktaran Pinar Bilgin, "Individual and Societal Dimensions of Security", International Studies Review, Vol. 5, No. 2, Jun. 2003, p. 209.

${ }^{53}$ Buzan, People, States and Fear: An Agenda for International Security Studies in the Post Cold War Period, a.g.e., p. 363. 
Değișen Güvenlik Anlayıșının

Uluslararası Örgüt Örnekleri Üzerinden Analiz Edilmesi

durumunda tehdit altında olacağını belirtir. $\mathrm{Bu}$ farklı kaynaklardan gelen tehditlerin arasında önem derecelerine göre sıralama yapmak da makul değildir. Çünkü önem dereceleri zamana ve koşullara bağlı olarak değişebilir. Örneğin, çevresel tehditler öncelikli olmayan tehditler olarak kabul edilebilir, ancak su kıtlığının tecrübe edilmesiyle askerî tehditlerin üstünde değerlendirilebilir. Askerî olmayan tehditlerin ortak yanları öngörülebilir olmayışlandır. Ne zaman ortaya çıkacakları da belirsizdir. Bu nedenle güvenlik meseleleri başka çerçevelerden ve askerî olmayan başka ihtimallerin de hesaba katılmasıyla ele alınmalıdır. ${ }^{54}$

Küreselleşme, güvenlik alanında yenilenmenin ortaya çıkmasını sağlayan en önemli gelişmelerdendir. Çünkü küreselleşme, sistem üzerinde anlayış değişikliğinin yaşanmasını sağlayacak koşulları şekillendiren etki yapmıştır. Sınırların geçirgenleşmesi, insan hareketliliğinin daha zor kontrol edilmesi, ticari faaliyetlerin denetlenmesi konusunda faaliyet gösteren mekanizmaların daha az çalıştırılması ya da işlevsizleşmesi, küreselleşme sonucunda gerçekleşmiştir. Bu gelişmeler insan kaynaklı tehditlerin artış göstermesinin önünü açmıştır. Terör saldırılanı, organize suç örgütlerinin etkinliklerini artırması, insan kaçakçılığı oranlarının artış göstermesi gibi yeni güvenlik sorunları, küreselleşmenin uluslararası sistemin farklı alanlardaki mekanizmasının işleyişinde meydan getirdiği değişimler sonucunda gerçekleşmiştir. Aslında bu tehditler Soğuk Savaş yılları boyunca da varlık göstermiştir ancak küreselleşme süreciyle yaşanılan değişim, bu tehditlerin daha etkin olarak varlık göstermeleri için uygun zemini oluşturmuştur. ${ }^{55}$ Küreselleşmeyle tehdit algisında meydana gelen en önemli değişim, tehditlerin tek boyutlu ve devletten devlete olan klasik tehditler olarak değil; çok boyutlu ve asimetrik tehditler olarak kabul edilmeye başlanmış olmasıdır. ${ }^{56}$

Küreselleşme, bireyin özgürleşmesi, kendi hayatı ve güvenliğiyle ilgili daha çok söz sahibi olması için koşulların oluşturulması aşamasında

\footnotetext{
${ }^{54}$ Buzan, a.g.e., pp. 134-141.

${ }^{55}$ Terry Teriff et. al., Security Studies Today, USA Polity Press, 1999, pp. 115-117.

${ }^{56}$ Bilal Karabulut, Güvenlik, Küreselleşme Sürecinde Güvenliği Yeniden Düşünmek, Barıș Kitap, Ankara, 2011, s. 6.
}

117

Güvenlik Stratejileri

Y11: 13

Sayl: 25 


\section{Özlem ÖZKÖSEDAĞ IÇCiN}

önemli rol oynamıştır. Geleneksel güvenlik anlayışında devletin güvenliğinin önceliklendirilmesi, devletin güvenliği için alınacak tedbirlerin vatandaşların özgürlük ve haklarının önüne geçmesine neden olmuştur. 1990'l y yllardan itibaren küreselleşme sürecinin de etkisiyle özgürlüklerin devlet güvenliğinin önünde değerlendirilmesiyle yeni güvenlik anlayışı ortaya çıkmıştır. ${ }^{57}$

Küreselleşme süreci insanların ulus devlet vatandaşlığından başka aidiyetleri ve kimliklerinin olduğunu göstermiştir. Ulus devlet yapılanmasının en ideal siyasal yapılanma olup olmadığ, küreselleşmenin oluşturduğu fikirsel altyapının desteğiyle sorgulanmıştır. Dolayısıyla ulus devletin hâkim unsur olduğu geleneksel güvenlik anlayışı, küreselleşmenin etkisiyle yenilenmeye başlanmıştır. ${ }^{58}$

Küreselleşme güvenliğin mekânsal boyutuna ilişkin değerlendirmelerin değişmesine de yol açmıştır. Çünkü küreselleşme sürecinin yol açtığı insan, sermaye ve mal değişiminde sınırların ortadan kalkması, uluslararası ilişkilerin devlet sınırlarından bağımsız hâle gelmesi, güvenlikle ilgili yeni değerlendirmelerin yapılmasına neden olmuştur. ${ }^{59} 1980$ 'lerden bu yana geleneksel güvenlik anlayışından

Security Strategies

Year: 13

Issue: 25 farklı olarak ortaya çıkan güvenlik kavramları arasında; ortak güvenlik, karşılıklı güvenlik, iş birlikçi güvenlik, güvenlik ortaklığı ve kapsamlı güvenlik sayılabilir. ${ }^{60}$ Neticede, küreselleşme süreciyle, güvenlik ulusal ve uluslararası güvenlik anlayışından küresel güvenlik anlayışına doğru evirilmeye başlamıştır.

Soğuk Savaş sonrası küreselleşmenin de etkisiyle ortaya çıkan yeni güvenlik alanları birey güvenliği, çevresel güvenlik, ekonomi güvenliği, sağlık güvenliği, demografik güvenlik, doğal kaynakların güvenliği, enerji güvenliği, gıda güvenliği, bilgi-bilişim ve teknoloji güvenliği olarak sıralanabilir. ${ }^{61}$ Bunlara toplumsal güvenlik ${ }^{62}$ de dâhil

\footnotetext{
${ }^{57}$ Oğuzlu, a.g.m., s. 6.

${ }^{58}$ Oğuzlu, a.g.m., s. 9.

${ }^{59}$ Brauch, a.g.m., s. 15.

${ }^{60}$ Brauch, a.g.m., s. 14.

${ }^{61}$ Karabulut, a.g.e., s. 123.
} 
Değișen Güvenlik Anlayıșının

Uluslararası Örgüt Örnekleri Üzerinden Analiz Edilmesi

edilebilir. Bu yeni güvenlik alanları ortaya çıkan tehditlerin birden fazla alanla ilgili sorun oluşturma kapasitelerinin olması nedeni ile birbirleriyle ilgilidir. Doğal kaynakları tehdit edecek bir sorun, kitlesel göçlere neden olabileceği gibi, neticede göç veren devletin ve göç alan devletlerin ekonomik güvenlikleri de tehlike altına girebilecektir. ${ }^{6 .}$

Yeni güvenlik anlayışına akademik alanda en önemli destek Kopenhag Okulu mensuplarından gelmiştir. Buzan'ın çalışmaları neticesinde, güvenlik başka boyutlarda ele alınmıştır. Bunlardan biri de toplumsal güvenliktir. Topluluğun kimliğine yönelik algılanan tehdide karşı savunulması olarak tanımlanabilecek toplumsal güvenlik, ${ }^{64}$ Soğuk Savaş sonrası dönemin üzerine çalışma yapılan en önemli güvenlik alanlarından biridir. Devletin askerî güvenliğinin sağlanmış olması, toplumsal güvenliğin sağlandığı anlamına gelmemektedir. Çünkü toplumsal güvenliğin konusu olan kimlikler devletten ayrı olarak teşekkül eder. Bu çerçevede, toplumsal güvenlik "kimlik güvenliği" olarak anlaşlabilir. ${ }^{65}$ Toplumsal güvenlik, güvenliğin hapsedildiği dar alandan çıkartılıp başka yönleriyle ele alınmasını sağlamış olan yeni güvenlik algısının bir parçasıdır.

Çevre güvenliği alanında yapılan çalışmalar da güvenlik anlayışının değiştiğini göstermektedir. Almanya'daki ve Avrupa'nın bazı bölgelerindeki asit yağmurları, küresel ısınma gibi olaylar dikkatlerin askerî güvenlikten yaşamın olmazsa olmazı çevreye kaymasına neden olmuștur. Neticede, çevre güvenliği endişeleri, devletleri rekabetçi yerine iş birlikçi çözümler bulmaya sevk etmiştir. ${ }^{66}$ Çünkü çevre sorunları sınır aşan niteliktedir; tek tek devletlerin etkili çözümler üretmeleri mümkün olmamaktadır.

Yeni güvenlik anlayışının ortaya çıkmasında teorik anlamda en

${ }^{62}$ Ole Waever, "Toplumsal Güvenliğin Değișen Gündemi", Uluslararası İlişkiler, Cilt 5, Sayı 18, Yaz 2008.

${ }^{63}$ Karabulut, a.g.e., s. 123.

${ }^{64}$ Waever, a.g.m., s. 153.

${ }^{65}$ Waever, a.g.m., ss. 153-155.

${ }^{66}$ Brauch, a.g.m., s. 5. 


\section{Özlem ÖZKÖSEDAĞ IC̣îN}

önemli katkılardan birini eleştirel güvenlik çalışmaları yapmıştır. Eleştirel teorisyenler için, devletler, farklı niteliklere sahip olmaları ve güvensizlik sorununun çözümünden ziyade parçası olmaları sebebiyle, güvenlik analizlerinin temelinde yer almamalıdır. Devletler, kendi halkları için güvenlik de sağlayabilir, tehdit kaynağı da olabilir. Bu sebeple, devlet yerine bireye odaklanılmalıdır. ${ }^{67}$ Eleştirel güvenlik çalışmaları, devletin önemli bir aktör olduğunu kabul eder; fakat bunu yaparken diğer aktörlerin gözden kaçırılmaması gerektiğini, diğer aktörlere yönelmiş tehditlerin hem devletlerin hem uluslararası yapının güvenliğini tehdit ettiğini belirtir. ${ }^{68}$ Eleştirel yaklaşımın farklı fraksiyonları güvenliğin tanımını genişletmiştir. Düşmanların ve savaşların olmadığı bir yapıyı mutlak güvenli olarak görmemiş; ekonomik, kültürel ve sosyal anlamda sorunsuz yapıları güvenli olarak tanımlamışlardır. Eleştirel çalışmaları ilk başlatan merkez olan Frankfurt Okulu'nun mensupları, birey ve özgürlüğünü önemli olarak kabul etmiş; modern yaşamın bireyleri özgürleştirmediğini, ürettiği yeni mitler aracılığıyla onları kontrol ederken sınırlandırdığını belirtmiştir. Modernizm ile birlikte insanların, özellikle mülkiyet kavramının doğurduğu eşitsizlikler nedeniyle özgürlükleri kısıtlandığ için, güvenlik problemleri yaşamaya başladığını söylemişlerdir. Özgürlüğü engellenen bireyin potansiyelinin sınırlandırıldığın; bu durumun da başlı başına güvenliği tehdit eden yeni durumların yaşanmasına yol açtı̆̆ını öne sürmüşlerdir. ${ }^{69}$

Eleștirel güvenlik çalışmaları yapanların ortak noktalarından biri de demokrasiye olan inançlarıdır. Kozmopolit demokrasi anlayışı, eleştirel çalışmalar yapanlar için ihtilaflı bir kavram olsa bile, genel olarak demokrasinin her yerde/alanda gelişmesinin desteklenmesinin gerekli olduğu savunmuşlardır. Devletler, BM gibi uluslararası örgütlenmeler, küresel etkinliği olan diğer örgütlenmeler, yerel örgütler demokrasiyi içselleştirir ve uygulamaya yansıtırlarsa, küresel bir

67 John Baylis, "Uluslararası İlişkilerde Güvenlik Kavramı", Uluslararası İlişkiler, Cilt 5, Sayı 18,Yaz 2008, ss. 69-85, s. 81.

${ }^{68}$ Kraus and Williams, a.g.e., p. xvi.

${ }^{69}$ Birdișli, a.g.e., ss. 52-57. 
Değișen Güvenlik Anlayıșının

Uluslararası Örgüt Örnekleri Üzerinden Analiz Edilmesi

demokrasi ortamının var olabileceğini varsaymaktadırlar. Onlara göre güvenliğin sağlanabilmesi için, demokrasinin varlığı ve uygulanması bir ön koşul olmakla birlikte, siyasal toplum yapısı hayata geçirilmeli; söylemler etik kaygılar çerçevesinde belirlenmeli; özgürleştirici siyasal yöntemler kullanılmalıdır. Özgürleştirme uygulanmadan kapsayıcı bir güvenlik anlayışının meydana gelmesi mümkün değildir. ${ }^{70}$ Eleştirel çalışma yapan akademisyenlerin görüşleri arasında, güvenliğin sağlanması amacıyla geleneksel güvenlik anlayışında kullanılanlardan farklı yöntemler önermeleri nedeniyle bir benzeşme mevcuttur.

Yeni güvenlik anlayışına bir diğer önemli katkı, feminist teorisyenlerden gelmiştir. Feminist teorisyenlere göre, güvenliği problemli yapan erkek egemen yaşam şekli, toplumsal yapı ve inanç sistemleridir. Tüm güvenlik problemlerinin temelinde cinsiyet ayrımı vardır. Kadınlar dünyanın her yerinde ve tarihin her evresinde erkek egemenliğine boyun eğmek zorunda bırakılmıştır. Bu ayrımcılık, baskı ve sömürüyü beslemiştir. Feministlere göre, erkek egemenliğine dayalı baskı ve sömürü düzeni, güvenlik sorunlarını besleyen şiddet, baskı, rekabet ve çatışmayı da gündeme getirmiştir. Savaş ve çatışmaların arkasında erkeklerin saldırgan doğalarının olduğunu söyleyen feminist teorisyenler, güvenlik ortamının oluşmasının ön koşulunun, sistemdeki erkek egemen yapının değiştirilmesi olduğuna inanır. ${ }^{71}$ Mevcut yapının değişmesinin güvenli yaşam için ilk adım olduğunu belirtirler. ${ }^{72}$ Feminist teoride, kozmopolit güvenliğin tesis edilmesi için kadınlara, sistemde daha çok yer verilmesi gerekli görülmüştür. Kadınlar, yeni nesilleri barış konusunda eğitme potansiyeline sahip olduğundan, bu insanların barış ve güvenlik konularına bakışını değiştirmeye yardımcı olacaktır. Feminist güvenlik anlayışında öncelikli olan insan

${ }^{70}$ Ken Booth, Dünya Güvenliği Kuramı, çev. Çağdaş Üngör, Birinci Baskı, Küre Yayınları, Ağustos, 2012, ss. 77-81.

${ }^{71}$ Birdişli,a.g.e., ss. 58-59.

72 Susan McKay, "Women, Human Security, and Peace-building: A Feminist Analysis", Conflict and Human Security: A Search for New Approaches of Peacebuilding (2004), IPSHU English Research Report Series No. 19, pp. 152-168.

\section{1}

Güvenlik Stratejileri

Y11: 13

Sayl: 25 


\section{Özlem ÖZKÖSEDAĞ IC̣îN}

güvenliğidir. Devlet merkezli güvenlik ve barış anlayışı, tüm dünyayı kapsayacak bir barış ortamının oluşmasına hizmet etmemektedir. $\mathrm{Bu}$ nedenle insan güvenliği anlayışının yerleştirilmesi gerekmektedir. Bu anlayış sayesinde insan ihtiyaçları ve çevresel gereklilikler çatışmalar olmadan karşılanabilecektir.

Feministlere göre, güvenliği tehdit eden en önemli unsurlardan biri; kadınları, çocukları ve sıra dışı grupları tehdit eden yapısal şiddettir. Yapısal şiddet kadınların, çocukların ve sıra dışı grupların hayatlarını etkilemektedir. Baskıcı sosyo-kültürel yapı, ekonomik sorunların sonuçları olarak ortaya çıkan işsizlik, açlık ve hastalık gibi tehditler, bireylerin yaşamını etkileyen yapısal şiddettin unsurlarıdır. ${ }^{74}$ Sosyokültürel özellikler ve siyasi-iktisadi yapıdaki sorunlar yapısal şiddeti beslemekte, şiddetin süreklilik kazanmasına neden olmaktadır. Böyle bir durumda, şiddet sistemleşmekte; aile içi şiddet toplumsal şiddeti; toplumsal şiddet de uluslararası anlaşmazlıkları beslemektedir. Her düzeydeki şiddet ve sorunlu yapılar birbirini desteklediğinden, uluslararası güvenliğin ya da ulusal güvenliğin diğer düzeylerde yaşanan sorunlardan soyutlanarak ele alınması, dolayısıyla güvenliğin, diğer düzeylerdeki sorunlu durumlara rağmen ulusal ve uluslararası düzeyde gerçekleştirilmesi mümkün değildir. Güvenlik problemleri arasındaki ilgileşim

Security Strategies

Year: 13

Issue: 25 belirlenmelidir. ${ }^{75}$ Feminist yaklaşım, eril güvenlik anlayışını değiştirmek için kadınların siyasal ve askerî kurumların ve örgütlenmelerin karar alma mekanizmalarında daha çok yer almalanı gerektiğini belirtmektedir. ${ }^{76}$ Karar verici konumuna yükselen kadınların güvenlik sorunlarının ele alınış şekillerini, farkı bakış açılarıyla, değiştirebileceğine

73 Ian Gibson, "Human Security: A Framework for Peace Constructs, Gendered Perspectives and Cosmopolitan Security", Journal of Peace, Conflict and Development, Issue 17, August 2011, pp. 85-86.

${ }^{74}$ Muhittin Ataman, "Feminist Yaklaşımlar ve Uluslararası İlişkiler Teorileri", , der. Tayyar Arı, Uluslararası İlişkilerde Postmodern Analizler 1. Kimlik Kültür Güvenlik ve Dış Politika, MKM Yayınları, Nisan 2012, s. 93.

${ }^{75}$ Eric M. Blanchard, "Gender,International Relations and the Developments of Feminist Security Theory", Chicago Journals, Vol 28, No.4, Summer 2003, pp. 1296-1298.

${ }^{76}$ Ataman, a.g.m., s. 92. 
Değișen Güvenlik Anlayıșının

Uluslararası Örgüt Örnekleri Üzerinden Analiz Edilmesi

inanılmaktadır. Böylece savaşın gerçekleşmesi ihtimali azalacaktır. Çünkü kadınlar çatışmaları önlemek, var olanları çözebilmek için şiddet içermeyen araçlanı, teknikleri ve stratejileri kullanmaktadır. ${ }^{77}$

Soğuk Savaş sonrası yeni dönemde, güvenlik artık sınırlar üstü bir durumdur ve akla ilk gelen güvenlik ise insan güvenliği olmaya başlamıştır. 1990'larda uluslararası ilişkiler disiplininin çalışma alanının insani kalkınma, kalkınma ve çatışma arasındaki ilişki, sınır aşan ve sayıları artan tehditler, gelişen uluslararası insani normlar gibi yeni unsurlarla zenginleşmesi, insan güvenliği kavramının doğmasına neden olmuştur. ${ }^{78}$ Zamanla ulus devletlerin dikkatini çeken insan güvenliği anlayışı, 2000'li yıllarda Japonya'nın resmî dış politikasının ana hedeflerinden biri olurken ${ }^{79}$ uluslararası örgütlerin de güvenlik tanımlamalarının bir parçası haline gelmiştir. Eski BM Genel Sekreteri Kofi Annan, güvenliğin yeni tanımını yapmış ve merkeze insanı koymuştur. İnsan güvenliğinin askerî anlamda güvenliğin sağlanmasından öte anlamlar içerdiğini belirtmiş; gerçek güvenlik durumunun barış kültürünün oluşturulmasıyla mümkün olduğunu vurgulamıştır. ${ }^{80}$ İnsan güvenliği anlayışı, ulus devletlerin güvenliğin sağlanmasından sorumlu sistemdeki tek aktör olduğu yönündeki kabule karşı çıkmış; uluslararası örgütlerin ve sivil toplum kuruluşlarının da bu konuda çeşitli fonksiyonlar üstlenebileceğini belirtmiştir. ${ }^{81}$

Yapılan teorik incelemelerden sonra değişen koşulların güvenlik anlayışındaki değişimi zorunlu kıldığı anlaşılmaktadır. Yeni şartlara uygun güvenlik/güvensizlik durum ya da durumlarını açıklamak için geliştirilen yeni güvenlik anlayışları, geçmiş dönemin şartlarına uygun

\footnotetext{
${ }^{77}$ Ataman, a.g.m., s. 94.

${ }^{78}$ Burak Tangör, "Kuramsal Tartışmalar Işı̆̆ı̆nda İnsan Güvenliği ve Politikaları", Uluslararası Hukuk ve Politika, Cilt. 8, Sayı: 30, ss. 59-92, 2012, s. 61.

${ }^{79}$ Gibson, a.g.m., p. 91.

${ }^{80}$ Kofi Annan, "Towards a Culture of Peace", Seçen, Federico Mayor- Roger-Pol Droit, Letters to Future Generations, UNESCO Publishing, s.15. Erişim tarihi: 15.02.2015, http://unesdoc.unesco.org/images/0011/001185/118573E.pdf.

${ }^{81}$ A. Şevket Ovalı, "Ütopya ile Pratik Arasında: Uluslararası İlişkilerde İnsan Güvenliği Kavramsallaștırması", Uluslararası İlişskiler, Cilt 3, Sayı 10, Yaz 2006, s. 6.
}

Güvenlik Stratejileri

Y11: 13

Sayı: 25 


\section{Özlem ÖZKÖSEDAĞ IÇCiN}

olan güvenlik anlayışının etkinliğini yitirmesine neden olmuştur. Uluslararası örgütler de yeni güvenlik anlayışına uygun olarak kendilerini yenilemişsir. Çalışmanın bu kısmında, konu NATO ve BM örnekleri üzerinden analiz edilmeye çalış1lacaktır.

\section{NATO, BM ve Yeni Güvenlik Anlayışı}

NATO, İkinci Dünya Savaşı'nın ardından SSCB'den algılanan tehdit neticesinde 1949'da kurulan ve üye devletlerin savunma örgütü olması amaciyla oluşturulan bir örgütlenmedir. BM Antlaşması'nın 51. Maddesinde ${ }^{82}$ belirtildiği üzere, BM, üye devletlerin öz ve ortak savunmalarını gerçekleştirebilmek için kurulmuştur. Örgüt geliştirilen stratejilerin rehberliğinde Soğuk Savaş yılları boyunca kuruluş amacına hizmet etmiş, fakat Doğu Bloğu'nun dağlmasıyla güvenlik alanında ilk sorgulanan konulardan biri NATO'nun varlık sebebi olmuştur. Varşova Paktı dağıldığı için NATO'ya ihtiyaç kalmadığı yönünde fikirler beyan edilirken, Avrupa'da yaşanılan çatışmaların NATO müdahalesiyle çözülmesi hâlâ etkili bir örgüt olduğunu göstermiştir. ${ }^{83} 1989$ tarihli Hükümet ve Devlet Başkanları Zirvesi sonuç bildirisine bakıldığında, NATO'nun değişimi takip ederek yeni döneme uygun bir güvenlik stratejisi geliştirmeyi hedeflediği anlaşılmaktadır. Bildiride, Sovyet Bloğu'nda yaşanılan değişimin, bazı eski Doğu Bloğu üyesi devletlerin serbest piyasa uygulaması denemelerinin ve demokratikleşme çalışmalarının takdir edildiği belirtilmiştir. Anti demokratik uygulamalara

devam eden yönetimler uyarılmış; Avrupa Güvenlik ve İşbirliği Konseyi (AGİK) vasıtasıyla gerçekleştirilecek görüşmeler sayesinde Batı ve Doğu Blokları arasında yapıcı diyalog ve iş birliğin sağlanacağ1 vurgulanmıştır. Yeni dönemde askerî rekabetin yerini iş birliği anlayışına, karşılıklı güven duygusuna, insan hakları ve siyasal özgürlüklere sayg1 anlayışına dayalı barışçıl ve yapıcı bir rekabetin alması gerektiği

${ }^{82}$ BM Kurucu Antlaşması 51. Madde için Bkz. https://treaties.un.org/doc publication/ ctc/uncharter.pdf.

${ }^{83}$ Abdulkadir Baharçiçek, "Soğuk Savaşın Anlamı ve Sona Ermesinin Türk Dış Politikası Üzerindeki Etkileri”, İdris Bal (der.), 21. Yüz Yılın Eșiğinde Türk Dıș

Politikası, 1. Baskı, Alfa Basım Yayım Dağıtım, 2001, s. 44. 
Değișen Güvenlik Anlayıșının

Uluslararası Örgüt Örnekleri Üzerinden Analiz Edilmesi

\section{belirtilmiştir. $^{84}$}

Soğuk Savaş sonrası NATO'da gözlemlenen değişim, güvenlik konusundaki anlayış değişikliğini en güzel yansıtan örneklerden biridir. NATO, Batı Bloğu'nun savunma örgütü olmaktan ziyade toplumsal, ekonomik ve siyasal işlevlerle donatılmış küresel güvenlik anlayışını benimseyen bir örgütlenme olma yolunda evirilmektedir. İnsan hak ve özgürlüklerinin, ulus devletlerin sinırlarının kutsallığının üzerinde tutulması anlayışı, yeni dönemde NATO'da çeşitli değişikliklerin yaşanmasına yol açmıştır. ${ }^{85}$ NATO güvenlik alanında yaşanan değişime uyumlu olarak kendini yenilemektedir. Bu yenileme, bir yanda kurumsal mekanizmada kendini gösterirken; diğer yanda güvenlik anlayışıı gösteren Strateji Konsepti Belgeleri'nde varlığını hissettirmektedir. 1999 ve 2010 Strateji Güvenlik Konseptlerinde, özgürlük, demokrasi, insan hakları ve hukukun üstünlüğü NATO'nun üzerinde yükseldiği değerler olarak tanımlanmıştır. ${ }^{86} \mathrm{Bu}$ değerlerin, askerî savunma amacı ile kurulmuş bir örgütün temel değerleri olarak tanımlanması, güvenlik algılamasında değişim yaşandığının göstergeleridir. NATO, 1999 Washington Zirvesi'yle birlikte "kapsamlı güvenlik kavramı stratejisi" konusunda fikir birliğini sağlamış; böylece güvenlik alanını genişletmiştir. Bu strateji kapsamında askerî kuvvetlerde indirim yapılmış, NATO üyesi olmayan devletlerde yaşanılan güvenlik sorunlarına dahi yeni oluşturulacak ve hareket kabiliyeti yükseltilmiş mobil kuvvetlerle müdahale edilebileceği kararlaştırılmıştır. Böylece, NATO üyeleri bir iç halka oluştururken üyelerin çevresi de dış güvenlik halkası kabul edilerek NATO'nun etkinlik alanı genişletilmiştir.

Güvenlikle ilgili anlayış değişikliğinin ilk sinyalleri, uygulamaya ilişkin olmuştur. Soğuk Savaş’ın sona ermesinden hemen

\footnotetext{
${ }^{84}$ Declaration of the Heads of State and Government, 29 May 1989, Erişim tarihi: 02.05.2015, http://www.nato.int/cps/en/natohq/official_texts_23554.htm?selectedLocale=en.

${ }^{85}$ Canbolat, a.g.e., ss. 101-102.

${ }^{86}$ Erdem Özlük ve Duygu Özlük, 'NATO'yu Anlamak: Dönüşümü, Yeni Kimlikleri ve Uyum Süreçleri”, Selçuk Üniversitesi Sosyal Bilimler Enstitüsü Dergisi, Sayl: 31, 2014, s. 211.
}

125

Güvenlik Stratejileri

Y11: 13

Sayl: 25 


\section{Özlem ÖZKÖSEDAĞ IC̣îN}

sonra, NATO üyesi olmayan devletlerle gevşek ittifak ilişkisi kurulmuştur. Gevşek ittifak ilişkisi anlayışı çerçevesinde, 1991 yılında Kuzey Atlantik İş Birliği Konseyi (KAİK) oluşturulmuştur. Eski Doğu Bloğu üyesi 22 devletle gerçekleştirilen bu konsey sonradan Barış İçin Ortaklık (BIO) ismi altında faaliyetlerini yürütmüștür. BİO uygulamaları marifetiyle sadece askerî değil, siyasi meselelerde ve çevre konularında da karşı1ıklı görüşme, danışma mekanizmalarının kurulması ön görülmüştür. Bu girişim, dağlan Sovyet Bloğu üyelerinin liberal dünyaya ve onun değerlerine uyum sağlamasını kolaylaştırmak için kullanılmıştı. ${ }^{87}$ NATO, bu girişimiyle güvenliğin askerî olmayan boyutlarının da var olduğunu kabul etmiş;; askerî anlamda güvenlik ortamını oluşturabilmek için bu ortamın devam etmesini sağlayacak yan koşulların oluşturulması konusunda harekete geçmiştir. Daha sonraki yıllarda dağılan Doğu Bloğu'nun bazı üyeleri NATO üyesi olmuştur. Bu gelişmelerle birlikte değerlendirildiğinde, NATO'nun güvenlik anlayışında ortaya çıkan değişikliğin de etkisiyle kolektif güvenlik örgütü olma yolunda ilerlediği iddia edilmektedir. ${ }^{88}$

11 Eylül terör saldırıları, Kosova ve Bosna'daki çatışmalar gibi uluslararası güvenliği tehdit eden olaylar NATO'nun güvenlik anlayışını değiştirmesini zorunlu kılmıştır. NATO 1999'da Yeni Strateji Konsepti'ni Soğuk Savaş sonrası koşullara uygun olarak geliştirmiş, yaşanılan gelişmelerin ardından 2010 yılında tekrar güncellemiştir. 1999 y1lı belgesinde güvenliği tehdit eden yeni riskler; siyasal, sosyal, ekonomik istikrarsızlıklar, milliyetçi ve etnik temelli çatışmalar, kitle imha silahlarının yayılması olarak sıralanmıştır. ${ }^{89} 1999$ Washington Zirvesi'nde kabul edilen Yeni Stratejik Konsept'te yeni tehditlere karş1 yeni uygulamaların geliştirilmesi gerektiği belirtilmiştir. Caydırma ve

${ }^{87}$ Beril Dedeoğlu, Uluslararası Güvenlik ve Strateji, 3. Baskı, Yeni Yüzyıl, İstanbul, 2014, ss. 321-322.

${ }^{88}$ Özlük ve Özlük, a.g.m., s. 212.

89 Alliance's Strategic Concept, Approved by the Heads of State and Government participating in the meeting of the North Atlantic Council in Washington D.C., issued on 23-24 April 1999, NATO Web Sitesi: http://www.nato.int/docu/pr/1999/p99-065e.htm. 
Değișen Güvenlik Anlayıșının

Uluslararası Örgüt Örnekleri Üzerinden Analiz Edilmesi

savunma, örgütün temel işlevleri olarak kabul edilirken, önleyici diplomasi ve kriz yönetimi gibi uygulamalar konseptte başvurulacak yeni yöntemler ve görevler olarak sayılmıştır. 2010 yılındaki belgeye bakıldığında, terörizmle mücadelenin birincil güvenlik gündemi haline geldiği anlaşılmaktadır. 2010 belgesinde risk ve tehdit tanımlamalarının yaşanılanlara bağlı olarak değiştiği görülmektedir. Belgeye göre, sınır aşan suçlar, iklim değişikliği ve çevre sorunları, enerji kaynaklarının birbirine bağlanması gibi sorunlar yeni güvenlik problemleridir. Bunlar askerî çözüm önerileriyle üstesinden gelinebilecek sorunlar değildir. Askerî olmayan araç ve yöntemlerin kullanılması zaruridir. Siber savunma, doğal kaynakların korunması, enerji güvenliği ve doğal afetlerde yardım gibi konular da NATO'nun faaliyet alanına dâhil edilmiştir. ${ }^{90} \mathrm{Bu}$ alanlarda faaliyet gösterebilmek için örgüt kendini yenilemek durumunda kalmıştır. ${ }^{91}$ Konseptlerden de anlaşıldığ NATO’nun yaşadı̆̆ bu değişimin nedenlerinden biri de güvenliği farklı açılardan tehdit eden yeni risklerin belirmiş olmasıdır.

2010 Yeni Stratejik Konsepti'nde yeni tehditlerle etkin mücadele için ekonomik ve siyasal araçların daha sık kullanılması gerektiği belirtilmiştir. Eski ve yeni ortaklarlarla iş birliği alanlarının ve iş birliği düzeyinin geliştirilmesi hedeflenmiştir. Rusya ile ilișkilerin geliştirilmesine özel önem atfedilmiştir. ${ }^{92}$ Esasında, NATO'nun yeni güvenlik anlayışı doğrultusunda ve dünya gerçeklikleri çerçevesinde güvenliğin tesis edilmesi için benimsediği yöntem, iş birliğidir. 1989 ve sonrasındaki NATO belgeleri incelendiğinde bu görülmektedir. NATO 1989'dan sonra güvenliği farklı boyutlanyla ele almaya başlamış;

${ }^{90}$ Strategic Concept for the Defence and Security of the Members of the North Atlantic Treaty Organisation Adopted by Heads of State and Government in Lisbon, 10 Nov 2010, Erişim tarihi: 01.09.2015, http://www.nato.int/cps/en/natohq/official texts_68580.htm?selectedLocale=en.

${ }^{91}$ Dedeoğlu, a.g.e., s. 329.

92 Strategic Concept for the Defence and Security of the Members of the North Atlantic Treaty Organisation Adopted by Heads of State and Government in Lisbon, 10 Nov 2010, Erişim tarihi: 01.09.2015, http://www.nato.int/cps/en/natohq/ official_texts_68580.htm?selectedLocale=en. 


\section{Özlem ÖZKÖSEDAĞ IC̣îN}

kapsamlı güvenliğin var olan başka örgütlenme ve kurumların desteğiyle sağlanabileceğini belirtmiştir. 1990' daki Londra Konferansi ${ }^{93}$ ve 1991 Temmuz'unda gerçekleştirilen bir başka toplantıyla NATO, güvenliği sağlamak için kullandığı yöntemi değiştireceğini, iş birliği esası üzerine kurulu güvenlik anlayışını hayata geçirme niyetinde olduğunu göstermiş̧tir. Bat1 Avrupa Birliği (BAB), AGİK, Avrupa Birliği (AB) ve Avrupa Konseyi (AK) iş birliği yapılacak örgütler olarak tespit edilmiştir. $^{94} 1999$ tarihli konsepte göre NATO, BM Güvenlik Konseyi'nin yanı sira AGIT'le birlikte hareket edecek; AGIT'in davet etmesi halinde barış koruma operasyonlarına katkıda bulunacaktır. ${ }^{95}$ NATO'nun gevşek yapılı bir iş birliği platformu olarak tanımlanabilecek AGITT'le birlikte hareket etmesi yaşadığı dönüşümü gösteren bir diğer gelişme olarak değerlendirilebilir. 2004 y1lında gerçekleștirilen İstanbul Zirvesi'nde daha önce başlatılan Akdeniz Diyalogu Platformu'nun Orta Doğu devletlerini de içine alacak şekilde genişletilmesi kararlaştırılmıştır. Bu kararla öncelikle savunma ve güvenlik alanlarında başlatılacak iş birliğinin zamanla diğer politika alanlarını kapsayacak şekilde genişletilmesi, geliştirilen iş birliği sayesinde güvenlik çemberinin genişletilmesi amaçlanmıştır. ${ }^{96} \mathrm{Bu}$ anlayış değişikliğin ilave olarak, 1999'da kabul edilen Yeni Güvenlik Stratejisi çerçevesinde NATO'nun

Security Strategies

Year: 13

Issue: 25 gerçekleştirdiği askerî operasyonlarda amaç değişikliğinin yaşandığı belirtilmelidir. Kosova olaylarına müdahale eden NATO'nun amacının toprak koruma olmadığı bildirilmiş; NATO'nun üzerine inşa edildiği ortak değerlerinden insan hakları, hürriyeti ve onurunun dokunulmazlığının

${ }^{93}$ Declaration on a Transformed North Atlantic Alliance "The London Declaration", 05-06 Ju1. 1989, Erişim Tarihi: 02.05.2015, http://www.nato.int/cps/en/ natohq/official_texts_23693.htm?selectedLocale=en.

${ }^{94}$ NATO's Core Security Functions in The New Europe, 06-07 Jun.1991, Press Rlease M-1(91) 44 44, Erişim Tarihi: 02.05.2015, http://www.nato.int/cps/en/ natohq/official_texts_23861.htm?selectedLocale=en.

${ }^{95}$ Mustafa Aydın ve Fulya Ereker, Türkiye'de Güvenlik Algı, Politika, Yapı, 1. Baskı, İstanbul Bilgi Üniversitesi Yayınları, İstanbul, Kasım 2013, s. 40.

${ }^{96}$ Istanbul Summit Communiqué, 28 June 2004, Erişim Tarihi: 03.05.2015, http://www.nato.int/docu/pr/2004/p04-096e.htm. 
Değișen Güvenlik Anlayıșının

Uluslararası Örgüt Örnekleri Üzerinden Analiz Edilmesi

ihlal edilmiş nedeniyle müdahalenin yapıldığı açıklanmıştır. ${ }^{97}$ Müdahale sonrasinda Kosova'ya tekrar istikrarın gelmesi amaciyla NATO yardımları devam etmiştir. ${ }^{98}$ Soğuk Savaş yıllarında ise üye devletlerin sinırlarının korunması temel güvenlik meselesi olarak tespit ediliyordu. Dolayısıyla tüm bunlar NATO'nun güvenlik sorunlarına artık sadece askerî perspektiften bakmadığını kanıtlar niteliktedir. NATO iş birliğine dayalı güvenlik anlayışıyla güvenlik alanını genişletmeyi hedeflemektedir. Küresel bir güvenlik ağı oluşturmaya çalışan NATO, merkeze de kendisini oturtmayı tasarlamaktadır. ${ }^{99}$ Güvenliğin küresel olarak ve değişik boyutlarıyla ele alınması bu çerçeveden bakınca sadece ulus devletler için değil; varlıklarını devam ettirmek isteyen uluslararası örgütlenmeler için de bir gereklilik halini almaktadır.

Özetle, NATO, Soğuk Savaş sonrası güvenliği tesis edip kalıcı kılmak için farklı yöntemlere başvurmuştur. Üye sayısını artırıp sahip olduğu değerleri daha geniş coğrafyaya yayarak ortak değer temelinde bir güven ortamının tesis edilmesini sağlamak istemiştir. 1994 ve sonrasındaki genişlemeler NATO'nun gelecekte de varlığın devam ettirecek bir örgütlenme olduğunun anlaşılmasını sağlamıştır. Aynı zamanda NATO bir zamanlar düşman kabul edilen Rusya'yla ortaklık antlaşması imzalamış; güvenliğin askerî rekabetle sağlanamayacak bir hâl aldığını anladığını göstermiştir. NATO uygulamalanı yeni güvenlik anlayışının Soğuk Savaş sonrası ayakta kalan tek savunma örgütlenmesi tarafindan benimsendiğini göstermiștir.

Soğuk Savaş sonrası BM'nin güvenlik anlayışında meydana gelen değişim de, yeni dönemin güvenlik durumunun iki kutuplu sistemden farklı olarak tezahür ettiğini göstermektedir. BM özellikle yeni dönemde insan güvenliği anlayışına vurgu yapmaktadır. Eski BM

97 Javier Solona, "NATO's Success in Kosovo", Foreign Affairs, Vol. 78, No. 6, November/December 1999, pp. 114-121.

98 George Robertson (Lord Robertson of Port Ellen), Kosova One Year On. Achievement and Challenge, Erişim tarihi: 10.05.2015. http://www.nato.int/ kosovo/repo2000/report-en.pdf.

${ }_{99}$ Dedeoğlu, a.g.e., ss. 330-331.

129

Güvenlik Stratejileri

Y11: 13

Sayl: 25 


\section{Özlem ÖZKÖSEDAĞ IÇCiN}

Genel Sekreterleri Boutros Ghali ve Kofi Annan, güvenliğin sadece askerî-siyasi güvenlik alanına sıkıștırılmaması gerektiği yönündeki düşüncelerini dile getirirken, BM'nin yeni koşullara uygun şekilde yeniden yapılanması küresel güvenlik ve yönetişimin sağlanması konusunda çalışmalar yürütmüştür. Aynı zamanda kolektif güvenlik ve küresel yönetişim gibi güvenlikle ilgili yeni kavramsallaşmaların oluşmasına katkıda bulunmuşlardır. ${ }^{100} \mathrm{BM}$, güvenliğin öncelikle insan unsuru dikkate alınarak tesis edilmesi durumunda sürdürülebilir olduğunu belirtmektedir. Örgüt, uluslararası sistemi tehdit eden çevre sorunları, salgın hastalıklar ve kitlesel yasadışı göç gibi tehlikelere dikkat çekmiştir. Bunlar askerî olmayan güvenlik tehditleridir. Bu kapsamda, yeni koşullar ve Dünya Şartı dikkate alınarak değerlendirme yapıldığında, BM sosyal ve ekonomik adalet olmaksızın barışın tesis edilemeyeceğine inandığını göstermiştir. Dünya Şartı, çevre, kalkınma, demokrasi ve barış sorunlarına ilişkin kapsayıcı çerçeve hükmünde iken, yeni nesil küresel varlık sorunlarına entegre çözümler üretecek temel bir çalışmadır. ${ }^{101}$ Dünya Şartı, AB gibi örgütlenmelere de rehberlik etmektedir. Bernstein'a göre, AB' nin küresel anlamda sistemde olumlu değişiklikleri yapabilen bir güce kavuşması, Dünya Şartı'nın değer temelli ve etik kaygılarla hazırlanmış düzenlemelerinin oluşturduğu zeminde daha kolaylaşacaktır. ${ }^{102} \mathrm{Bu}$ çerçeveden bakılınca, BM, Soğuk Savaş sonrası dönemde güvenlik anlayışının yenilenmesi konusunda etkili çalışmalar yapmakta ve diğer aktörlere rehberlik etmektedir.

BM, tıpkı NATO'nun yaptığ gibi yeni güvenlik anlayışına uygun yeni yöntemler geliştirme stratejisini benimsemiştir. Özellikle insan güvenliği anlayışı çerçevesinde, insanların güvenliğini tehdit eden tehlike o

${ }^{100}$ Nihal Ergül, "Yeni Güvenlik Anlayıșı Kapsamında Birleșmiş Milletler' in Rolü ve Uygulamaları", Atilla Sandıklı (der.), Teoriler Işı̆ğında Güvenlik, Savaş, Barış ve Catışma Çözümleri, Bilgesam Yayınları, İstanbul, 2012, s. 183.

${ }_{101}$ Johannah Bernstein, The Policy Relevance of the Earth Charter for Europe: A Paper Prepared for the Maastricht Forum on the Future of Europe, Maastricht University Press, Earth Charter International, Hollanda 9-11 May 2007, p. 16.

${ }^{102}$ Bernstein, a.g.y., p. 17. 
Değișen Güvenlik Anlayıșının

Uluslararası Örgüt Örnekleri Üzerinden Analiz Edilmesi

insanların hükümetlerinden dahi gelse, insani amaçlar çerçevesinde müdahalenin yapılabileceği belirtilmiştir. Güvenlik Konseyi'nin 688 sayılı kararıyla Irak'a yapılan müdahale, 794 sayılı kararıyla Somali'ye yapılan müdahale, adı geçen devletlerin içişlerine müdahale olarak adlandırılabileceği gibi, BM'nin yeni güvenlik anlayıșının ürünleri olarak da örnek gösterilebilir. ${ }^{103} \mathrm{Bu}$ müdahalelerle $\mathrm{BM}$, insan güvenliğinin, klasik güvenlik anlayışından farklı olarak devlet güvenliğinden sonra gelmediğini göstermiştir. Rothschild, BM'nin değişen güvenlik anlayışının, Soğuk Savaş sonrası güvenlik anlayışını yansıttığını belirtirken; Ghali'nin konuşmasındaki ülkesel güvenlik anlayışından tek tek bireylerin güvenliği anlayışına geçişini BM'nin değişen algılamasının göstergesi olarak sunar. Kısacası BM de 1990'lardan itibaren güvenliğin alanının genişlediğini kabul etmektedir. ${ }^{104}$

İnsan güvenliği anlayışı, BM'nin yaptığı tanımlamayla ayakları yere basar hale gelmiştir. Birleşmiş Milletler Kalkınma Programı (UNDP) tarafindan yapılan tanıma göre, insan güvenliği kronik tehditler olan açlık, hastalık, engellenme ya da baskılardan ve günlük yaşamı tehdit eden tehlikelerden uzak olma halidir. ${ }^{105}$ UNDP raporunda, güvenliğin uzun bir dönem insanlardan çok devletleri ilgilendiren bir kavram olarak görüldüğü belirtilirken, insan güvenliğini oluşturan yedi temel boyuttan bahsedilir. Bunlar; ekonomik güvenlik, gıda güvenliği, sağlık güvenliği, çevresel güvenlik, kişisel güvenlik, toplum güvenliği ve politik güvenliktir. Bu boyutlarda güvenlik sağlandığında insan güvenliği de sağlanabilecektir. ${ }^{106}$ Görüldü̆ğï gibi, raporda insan güvenliğí, güvenliğin başka boyutlarıyla birlikte ele alınmaktadır. Bu alanları da kapsayan

\footnotetext{
${ }^{103}$ Ergül, a.g.m., s. 185 .

${ }^{104}$ Emma Rothschild, "What Is Security?", Daedalus, Vol. 124, No. 3, The Quest for World Order, Summer, 1995, pp. 53-98, p. 56.

${ }^{105}$ UNDP, Human Development Report 1994, Oxford University Press, New York, 1994, ss. 22-23, Erişim tarihi: 15.12.2014, http://hdr.undp.org/sites/default/files/ reports/255/hdr_1994_en_complete_nostats.pdf.

${ }^{106}$ UNDP, a.g.e., pp. $24-25$.
}

131

Güvenlik Stratejileri

Y11: 13

Sayı: 25 


\section{Özlem ÖZKÖSEDAĞ IÇCiN}

konularda tesis edilecek güvenliğin, insanın insan olmasından ötürü kazandığı iyi şartlar altında ve güven içinde yaşama hakkının teslim edilebilmesi için gerekli olduğu vurgulanmaktadır. ${ }^{107}$

$\mathrm{BM}$, sivil inisiyatifler tarafindan barışın tesis edilmesi için yapılan girişimlere destek vermektedir. The Hague Agenda tarafindan düzenlenen the Hague Appeal for Peace Conference, ${ }^{108}$ bunlara verilebilecek bir örnektir. Geniş katılımlı olan bu konferansın amacı, devletler üstü işleyen bir mekanizma inşa edip siviller düzeyinde girişimlerin yapılmasını mümkün kılarak tüm dünyaya hâkim olacak barış kültürünü oluşturmaktır. ${ }^{109}$ BM'nin Genel Sekreter düzeyinde katılım gösterdiği bu girişim, barış halini sadece devletlerarasında savaş olmaması durumu olarak değil, toplumda sosyal ve ekonomik adaletsizliklerin olmaması durumu olarak tanımlamaktadır. İnsanın ve onun ihtiyaçlarının güvenlik politikalarının öncelikli konuları olması gerektiği yönünde inancı destekleyen bu tür girişimler, devletlerden bağımsız ve onların üstünde güvenlik durumlarının inşa edilebilmesi için gerekli kabul edilmektedir.

Yeni güvenlik anlayışı, güvenliğin yeni ve asimetrik tehditler

Security Strategies

Year: 13

Issue: 25 tarafından tehdit edildiği inancına dayanır. Belirtildiği gibi, sınır aşan nitelikteki tehditlerle devletlerin tek başlarına mücadele etmesi mümkün değildir. BM, 31 Ocak 1992 tarihli bildirisinde güvenliğin ekonomik, çevresel, sosyal boyutlarının olduğunu vurgulamış; bu alanlarda beliren güvenlik sorunlarının çözüm beklediğinin altını çizmiş; yeni sorunlar konusunda BM'nin neler yapması gerektiği sıralanmıștır. Zamanın BM Genel Sekreteri Ghali'nin hazırladığı Barış İçin Gündem Raporu'nda dünya güvenliğinin içinde bulunduğu durum resmedilmiş; yeni sorunların ve muhtemel çatışmaların nasıl engellenebileceği belirtilmiştir. Devletlerin iç güvenlik meselesi olarak

${ }^{107}$ Commission on Human Security, Human Security Now, UN Publications, New York, 2003, ss. 10-12.

${ }^{108}$ Daha geniş bilgi için bkz. Gipson, a.g.m., pp. 94-97.

${ }^{109}$ Gouri Sadhwanii The Hague Appeal for Peace Conference, http://www.mediate. com/articles/hague.cfm, Erișim tarihi: 11.09.2014. 
Değișen Güvenlik Anlayıșının

Uluslararası Örgüt Örnekleri Üzerinden Analiz Edilmesi

adlandırdığı sorunların kolektif güvenliği tehdit ettiği ve bunlara çözüm üretilmesi gerektiği anlatılmıştır. İnsan güvenliğinden bahsederken, BM'nin bütün organlarının ortak bir insan güvenliği anlayışı oluşturulması amacına yönelik önemli ve vazgeçilmez rollerinin olduğu da eklenmiştir. ${ }^{110}$ Güvenlik Konseyi toplantısında da uluslararası güvenliğin sağlanması için güvenliğin sadece askerî boyutunun değil, özellikle ekonomik ve sosyal boyutlarının üzerinde durulması gerektiği belirtilmiștir. $\mathrm{Bu}$ bağlamda, ekonomik kalkınmışlığın sağlanması ve sürdürülebilir kalkınmanın önemi vurgulanmış; demokrasi uygulamalarının yerleşmesine de destek olunması gerektiği bildirilmiştir. ${ }^{111} \mathrm{Bu}$ dokümanlardan da anlaşıldığı gibi, BM kendine yeni dönemde yeni bir güvenlik vizyonu oluşturmuş; eylemlerini de bu anlayışa uygun olarak gerçekleştirmiştir.

BM Genel Sekreteri Kofi Annan tarafindan hazırlanan ve sonrasında milenyum toplantısında raporlaştırılan "We the peoples: The Role of the United Nations in the 21th Century" başlıkl çalışma, BM'nin güvenlik alanında farklı alglamalar geliştirdiğine dair belgelerden biri kabul edilmektedir. Yeni güvenlik anlayışının silahsızlanmayı ve savaşların olmamasını zorunlu kılan ve tekil olarak bireylerin iyi hal durumlarına odaklanan insan güvenliği anlayışının geliştirilmesini teşvik ettiği belirtilmekte ve bu bağlamda BM'nin üstleneceği rollerden bahsedilmektedir. ${ }^{112}$

BM'nin mevzuat düzenlemelerinde görülen zihniyet değişiminin uygulanmaya konulması ise biraz daha vakit almıştır. Nitekim Yugoslavya krizinde, yaşanılan insanlık suçlarına rağmen gerekli müdahalenin

\footnotetext{
${ }^{110}$ Report of the Secretary-General, An Agenda for Peace Preventive diplomacy, peacemaking and peace-keeping, A/47/277 - S/24111 17 June 1992, Erişim tarihi: 10.09.2015. http://www.unrol.org/files/A_47_277.pdf.

${ }^{111}$ Repertoire of the Practice of the Security Council, Decision of 31 January 1992 (3046th meeting): statement by the President, Erişim tarihi: 10.09.2015, http://www.un.org/en/sc/repertoire/89-92/Chapter\%208/GENERAL\%20ISSUES/Item \%2028_SC\%20respons\%20in\%20maint\%20IPS.pdf.

${ }^{112}$ Kofi Annan, We the Peoples: The Role of the United Nations in the 21th Century, Erişim tarihi: 5.10.2015, http://www.un.org/en/events/pastevents/pdfs/We_The_Peoples.pdf.
}

133

Güvenlik Stratejileri

Y11: 13

Sayı: 25 


\section{Özlem ÖZKÖSEDAĞ IÇCiN}

yapılaması BM'nin sorgulanmasına neden olmuştur. $\mathrm{Bu}$ eleştiriler sonucunda BM yapısal yenilenmesini gerçekleştirmiştir. ${ }^{113}$ Esasında, BM, Soğuk Savaş dönemi bitince kendi içinde kurumsal anlamda değişikliğe gitmiştir. Burada yeni koşullara uygun olarak kendini dönüştürme ihtiyacının ortaya çıkması ve iki bloklu yapının kontrol edici etkisinin azalmış olması rol oynamıştır. Aynı zamanda kendi içinde yer alan bazı ajans, program ve kuruluşları da daha etkin olarak kullanmaya başlamıştır. Örneğin UNDP daha etkin kullanılmaya başlanan bir program olmuştur. Dünya çapında etkinlik sayısını artıran UNDP, 2030 yılına kadar gerçekleştirilecek sürdürülebilir kalkınma hedefleri ismi altında ekonomik, sosyal ve çevresel unsurları içeren bir program kabul etmiştir. ${ }^{114}$ Belirlenen küresel ölçekteki hedeflere ulaşılması ile dünya barışına, dolayısıyla güvenliğe katkı sağlanacaktır. Bu da BM'nin yeni güvenlik anlayışının gerekleri çerçevesinde belirlenmiş somut programının olduğunu göstermektedir. BM güvenlik alanında, sorun çözen mekanizma niteliğini güçlendirmek amacıyla, aralarında sebep sonuç ilişkisi ya da organik bağlar bulunan sorunlarla ilgilenmesi için ofisler kurmuştur. Var olan programlar, ofisler ve bölümler yenilenerek etkililik dereceleri artırılmak istenmiştir. Bu uygulamaya örnek olarak Birleşmiş Milletler Uyuşturucu ve Suç Ofisi (UNODC) gösterilebilir. UNODC daha önce var olan Birleşmiş Milletler Uluslararası Uyuşturucu Kontrol Programı (UNDCP) ile Suç Önleme ve Ceza Adaleti bölümlerinin birleştirilmesiyle kurulmuştur. Ofis, yasadışı uyuşturucu ticareti suçlarının önlenmesi, bunlarla mücadele edilmesi, uluslararası terörizm ve siyasal yolsuzluklar konularında düzenli ve kapsamlı çalışmalar yapılması, nihayetinde bu suçlara çözüm bulunmasında BM'ye yardımcı olması amaciyla kurulmuştur. ${ }^{115}$ Ofis'in mücadele ettiği sorunlar yeni güvenlik anlayışı çerçevesinde güvenliği tehdit eden sınır aşan tehlikeler olarak tanımlanmaktadır. UN Women ise

${ }^{113}$ Ergül, a.g.m., s. 186.

${ }_{114} \mathrm{http} / / /$ www.undp.org/content/undp/en/home/mdgoverview/, Erişim tarihi: 01.09.2015.

115 http://www.unodc.org/unodc/en/about-unodc/index.html?ref-menutop, Erişim tarihi: 01.09.2015. 
Değișen Güvenlik Anlayıșının

Uluslararası Örgüt Örnekleri Üzerinden Analiz Edilmesi

2010 yılında BM'nin kurumsal mekanizmasinda reform programı dâhilinde kurulmuş̧ur. Amacı, küresel düzeyde cinsiyet ayrımcılığının önlenmesi ve kadınların desteklenmesidir. ${ }^{116}$ UN Women, feminist güvenlik anlayışının BM düzleminde karşılık bulduğunun göstergesidir. Kadın haklarının uygulanmaya konulması yöntemiyle insan güvenliği anlayışında yol kat edilmektedir. Birleşmiş Milletler İnsan Yerleştirme Programı (UN Habitant), BM Genel Kurulu'nun 2002 tarihli kararına dayanarak faaliyet göstermektedir. Program daha önce merkez olarak rol üstlenmekle birlikte, 2002'de statüsünün güçlendirilmesi amacıyla program haline dönüştürülmüştür. Özellikle şehirleşmenin artması ve bunun neden olduğu sorunların güvenliğin çevresel ve insani boyutlanı üzerinde sonuç doğurmaya başlaması, BM'nin güvenliğin bu alanlarında da çalışmasını gerekli kılmıştır. Bu nedenle BM, UN Habitat'ın bütçesini artırmış, teşkilatlanmasının genişlemesini sağlamıştır. ${ }^{117}$ Birleşmiş Milletler Mülteciler Yüksek Komiserliği (UNHCR), BM'nin toplumsal güvenlik ve insan güvenliği çerçevesinde faaliyet gösteren komiserliğidir. Bütçesi zaman içinde büyüyen komiserliğin, 2015 y1lı kaynağı yedi milyar dolar olarak belirlenmiştir. ${ }^{118}$ Mültecilerin, özellikle mülteci çocuk ve kadınların güvenliğinin tesis edilmesi ve standartlarını yükseltilmesi amaciyla harcanan bu kaynak, BM'nin güvenlik anlayışındaki değişimin göstergelerindendir. BM, kendine bağlı komiserlikleri, programlan ve bunların rapor ve çalışmalanı aracılığıyla dikkatleri yeni güvenlik sorunlarına çekmekte ve bu alanlarda ortak bilinç oluşturmaya çalışmaktadır. $\mathrm{Bu}$ da BM'nin ulus devlet güvenliği anlayışından uzaklaştığını göstermektedir. BM'nin güvenlik anlayışını yenilenmesini zorunlu kılan, sadece sistemsel değişim değildir, aynı zamanda küreselleşme sayesinde artık kontrol edilemeyen iletişim imkânlanı da uluslararası kamuoyunun taleplerine cevap verilmesini örgüte dayatmaktadır.

\footnotetext{
${ }^{116} \mathrm{http}: / /$ www.unwomen.org/en/about-us/about-un-women, Erişim tarihi: 01.09.2015.

$117 \mathrm{http} / / /$ unhabitat.org/about-us/history-mandate-role-in-the-un-system/, Erişim tarihi: 02.09.2015.

${ }^{118}$ http://www.unhcr.org/pages/49c3646cbc.html, Erişim tarihi: 02.09.2015.
}

\section{5}

Güvenlik Stratejileri

Y11: 13

Sayı: 25 
Özlem ÖZKÖSEDAĞ IÇIN

Uluslararası örgütlerin yeni dönemde uluslararası değerlerin koruyuculuğunu, temsili ve yayginlaştırılması görevini üstlenmiş olmaları, güvenliğin yerleştirilmesi için askerî önlemlerin yeterli olmadığ anlayışının örgütlerin karar verici mekanizmaları tarafindan kabul edildiğini göstermektedir. Soğuk Savaş sonrası, NATO, savunma örgütü olmaktan öteye geçmiş ve bir iş birliği platformu haline gelmiş ve yayınladığı belgelerle güvenliğin farklı boyutları olduğunu göstermiştir. BM ise yeni güvenlik anlayışının ilham kaynağı ve aynı zamanda ürünü olan insan güvenliği anlayışının küresel olarak kabul edilmesini sağlama amacıyla çalışmalar yürütmektedir. Bu bağlamda, BM, Soğuk Savaş döneminden farklı fonksiyonları yerine getirmektedir. Elbette tüm bunlar koşullarda, sistemde tehdit ve risk algilamasında meydana gelen köklü değişlikler neticesinde, güvenlik anlayışının değişmesi ile mümkün olmuştur.

NATO ve BM gibi uluslararası sistemin aktörleri arasında zikredilen örgütlerin yeni güvenlik anlayışı çerçevesinde mevzuat ve uygulamalarında yenilenmeye gitmiş olması, sistemde etkili aktör olmak isteyen diğer aktörlere de rehberlik etmesi açısından önemlidir.

Security Strategies

Year: 13

Issue: 25

Soğuk Savaş sisteminin güvenlik anlayışına takılıp kalan aktörler sert güçlerini artırırken, diğer güç alanlarına yeterince yatırım yapamayacaktır. Oysa dünyada varlığ kabul edilen ve etkili güç olmak isteyen aktörlerin farklı güç alanlarına ilişkin potansiyellerini destekleyecek girişimlerde ve eylemlerde bulunması bir zorunluluk halini almıştır. Sadece askerî gücüne yatırım yapan fakat geniş halk kitleleri üzerinde nüfuz sağlayacak yumuşak güç ya da her ikisinin de makul oranda kullanımı olarak tanımlanabilecek akıllı güç araçları kullanılmadan gücün etkinlik alanını artırmak mümkün olmayacaktır. Bahsi geçen örgütler gerekli değişiklikleri yaparak dünya gerçekliklerine adapte olmuş ve bu sayede gelecekteki varlıklarını da garantilemeye çalışmıştır. Yeni anlayışı özümseyerek NATO örneği düşünüldüğünde etkinlik anlamında coğrafi sığlıktan da kurtulabilmişlerdir. Neticede yeni güvenlik anlayışına uyum sağlayan aktör sistemde yaşanan değişimi anladığını gösterirken, bunu kendisi için bir firsata dönüştürme imkânına da sahip olmaktadır.

Her iki örgüt de güvenlik anlayışlarını revize ederek, uluslararası siyasette etki edebilecekleri konuların kapsamını genişletmiştir. Ulus 
Değișen Güvenlik Anlayıșının

Uluslararası Örgüt Örnekleri Üzerinden Analiz Edilmesi

devletlerin sınır güvenliğinden ziyade küresel güvenlik anlayışını destekleyerek saygınlık düzeylerini artırırken politik kararlarının desteklenme ihtimalini de artırmışlardır.

\section{Sonuç}

Güvenliğin geleneksel yorumunda devletlerin varlıklarının devam ettirilmesi temel güvenlik meselesi iken, yeni güvenlik anlayışında sadece devletlerin fiziksel varlıklarının devam ettirilmesi üzerine odaklanılmaz; değerlerin korunması, toplumsal ilişkilerin muhafaza edilmesi, insanların fiziksel varlıkları ve hayat standartlarının korunup geliştirilmesi güvenlik konularına dâhil edilir. ${ }^{19}$ Yeni güvenlik anlayışı merkeze insanı koyarak ve yeni tehditleri değerlendirerek, güvenliğin başka alanlarda da inşa edilmesi gerektiğini iddia etmektedir. Geleneksel güvenlik anlayışını benimseyenler ise bunun güvenliğin alanının aşın genişlemesine neden olacağl, böylece bu alanda yapılan çalışmaların açıklayıcı olmaktan uzaklaşacağı gerekçeleriyle önceliği askerî meselelere vermeye devam etme taraftarıdır. Örneğin Miller'e göre, kutuplaşmanın bitmiş olması savaş tehdidin de bittiği anlamına gelmemektedir. Sistem hâlâ anarşiktir. Balkanlar'da yaşanılan çatışmalar da askerî tehditlerin öncelikli sorun olarak ele alınmasının gerekli olduğunu göstermektedir. ${ }^{120}$ Yine, Walt, güvenlik çalışmalarına pek çok yeni tehdidin eklenebileceğini fakat bunun güvenlik çalışmalarının sınırlarını çok genişleteceğini belirtirken, bu tehditleri ortadan kaldırmaya yönelik etkin politikaların oluşturulmasının güçleşeceği üzerinde durmaktadır. ${ }^{121}$ Walt, yeni tehditlerin ortaya çıkmış olmasının savaşların sebep olacağı yıkımı ortadan kaldırmadığını vurgularken, ulusal güvenlik kapsamında askerî tehditlerin öncelikli olarak çalışmalarda dikkate alınması gerektiğini savunmaktadır. ${ }^{122} \mathrm{Bu}$ bağlamda, Soğuk Savaş sonrası tehditlerin çeşitlenmesi, realistlere göre, yapılan güvenlik çalışmalarında köklü bir anlayış değişikliğini zorunlu kılmamaktadır. Çevre sorunlanı, küresel

\footnotetext{
${ }^{119}$ Karabulut, a.g.m., s. 2.

${ }^{120}$ Miller, a.g.m., p. 24.

${ }^{121}$ Walt, a.g.m., p. 213

${ }^{122}$ Walt, a.g.m., p. 217
} 


\section{Özlem ÖZKÖSEDAĞ IÇCiN}

1sınma ve ozon tabakasının delinmesi tek başlarına önemli sorunlar olsa ve insan yaşamını tehdit etse bile güvenlik çalışmalarının çerçevesini belirleyecek kadar önemli değildir. Ancak bu sorunlar nedeniyle savaş çıkacak olursa ya da çıkma ihtimali belirirse, o vakit güvenlik çalışmalarına dâhil edilmelidir inancı hâkimdir. ${ }^{123} \mathrm{Bu}$ bilgilerden hareketle, realist güvenlik anlayışının askerî olmayan tehditlerin güvenlik sorunu olarak değerlendirilmemesi gerektiği sonucuna varılmaktadır. Daha doğrusu realistlerin güvenliğin kapsamını ulusal ve uluslararası askerî çatışmalar, bunların önlenmesi ve nedenleri gibi başlıklar çerçevesinde şekillendirdiği anlaşılmaktadır. Bu nedenle askerî çatışmaya neden olma potansiyeli taşımayan ve devletlerin ulusal güvenlikleri tehlikeye atmayacak olan yeni döneme ait tehditler temel güvenlik problemleri olarak değerlendirilmez.

Buna karșın, Krahmann, askerî olmayan tehditleri devlet kaynaklı olmayan tehditler olarak adlandırır. Soğuk Savaş sonrası iç savaşlar ve terörizm gibi devlet kaynaklı olmayan tehditler devletlerarası savaştan alglanan tehditlerin yerini almıştır. Artık bir üçüncü dünya savaşının yaşanması beklenmemektedir, fakat küreselleşme ve gelişen karşı1ıklı gelmektedir. Kitlesel göç hareketleri sonucunda devletlerdeki göçmen nüfusunun artmasıyla temel mal ve hizmetlerin ve enerji kaynaklarının fiyatları yükselmekte; bu da ekonomik ve toplumsal sorunların yaşanmasına neden olmaktadır. Uluslararası etkileşim artarken devletlerin egemenlik alanlarında kontrolü azalmakta ve devlet kaynaklı olmayan tehditler daha kolay varlık sorunları hâline gelebilmektedir. ${ }^{124}$ Yeni tehditler, özellikle çevresel olanlar, sınır aşan mahiyettedir. $\mathrm{Bu}$

${ }^{123}$ Sean M. Lynn-Jones, "International Security Studies after the Cold War: An Agenda for the Future", CSIA Discussion Paper 91-11, Kennedy School of Government, Harvard University, December 1991. pp.5-6. Erişim tarihi: 04.03.2015, http://live.belfercenter.org/files/disc_paper_91_11.pdf.

124 Elke Krahmann, "Security Governance and Networks: New Theoretical Perspectives in Transatlantic Security", Cambridge Review of International Affairs, Vol. 18, No. 1, April 2005, pp. 16-17. 
Değișen Güvenlik Anlayıșının

Uluslararası Örgüt Örnekleri Üzerinden Analiz Edilmesi

tehditlerle mücadele bireylerin, toplumların, devletlerin ve uluslararası kurumsal mekanizmaların birlikte hareket etmesiyle mümkün olmaktadır. ${ }^{125}$

Soğuk Savaş dönemi ve sonrasında yapılan güvenlik çalışmalarının arasında gözlemlenen farklılık, güvenlikten ne anladıkları konusunda kendini göstermektedir. 1990'dan sonra yapılan çalıșmalarda realist retoriğe ait güvenlik anlayışına yöneltilmiş eleştiriler mevcuttur. $\mathrm{Bu}$ dönemden itibaren yapılan çalışmalarda "uluslararası güvenlik" anlayışından küresel güvenlik anlayışına doğru bir geçişin olması gerektiği vurgulanmaktadır. Artık yeni çalışmalara ilham kaynağı olan düşünce, küresel varoluşun güvenliğini sağlayacak güvenlik politikalarına rehberlik edebilmektir.

Küreselleşmenin de etkisiyle güvenlik başka boyutlarıyla ele alınmaya başlandığı zaman, uluslararası örgütler de kendilerini bu yeni anlayışa uygun olacak şekilde yenilemek zorunda kalmıştır. NATO ve $\mathrm{BM}$, yeni döneminin güvenlik problemlerinin eski dönemin yöntemleriyle çözülemeyeceğinin bilinciyle kendilerini yeni olana uygun hâle getirmiştir. Güvenliği farklı boyutlarıyla ele almışlar, özellikle iş birliği ve diyalogu güçlendirerek değer temelli strateji ve anlayış değişikliğini yaparak güvenliği kalıcı kılmak istemişlerdir. Sadece devletlerin değil, toplumların, bireylerin güvenlik problemlerini güvenlik ajandalarına not etmiş; insan güvenliğinin sağlanmadığı durumda kapsamlı güvenliğin gerçekleşemeyeceğinin farkına varmışlardır. Geleneksel güvenlik anlayışı çerçevesinde kurgulanan NATO ve BM, yeni koşullara uygun olacak şekilde güvenlik anlayışlarını yenilememekle kalmamış; güvenliğin farklı alanlarda tesis edilmesi neler yapılması gerektiğini de belirtmiştir. Yeni şartlara uygun olarak güvenliği tesis edilmesi çalışmalarına katkıda bulunabilmek amacıyla hızlı bir dönüşüm yaşamışlardır. Soğuk Savaş döneminin eseri olan bu iki örgütün geçirdiği değişim, yeni güvenlik anlayışının örgütler düzeyinde de kabul

\footnotetext{
${ }^{125}$ Joseph S. Nye, Understanding International Conflicts. An Introduction to Theory and History, Longman, USA, 2003, p. 250.
}

139

Güvenlik Stratejileri

Y11: 13

Sayl: 25 


\section{Özlem ÖZKÖSEDAĞ IÇCiN}

edildiğinin göstergesi olması açısından önem arz etmektedir.

\section{Summary}

Security, which is evaluated within the framework of the entity problem, has been identified as one of the areas of international politics after the Second World War. It conceptually has a history as deep as the history of human being and gains meaning with risk and threat concepts. The end of the Cold War has caused changes in security perceptions, as well as in other sectors. In the new era, the system is altered due to the fundamental changes in conditions. Individuals, international organizations, international companies, national and international community are being accepted as new actors now. Globalization makes the relations between the actors of the system more complicated, while increasing interdependency among them. The above summed up "change" has brought the question of "whose security?" to mind. After the end of the Cold War, a discussion also started about how and by which instruments should the security be ensured.

Security, on whose definition there is no consensus, is evaluated within the framework of national security by the traditional security concept. In this concept, the important thing is to ensure military and political security of the nation state. National borders are untouchable and sovereignty is indivisible. According to the traditional security concept, which is represented by realist thought, security problems are constant, due to either human nature or structural factors. States have to rely on their own power and abilities to ensure security because collaborations do not make sense in most cases.

Contrary to these views, new security concept positions the individual and the society into the center of security. It evaluates security with different actors and different dimensions. Environment, society, and economy are identified as new areas in security by Buzan. The new security concept states that the system has changed and the risks and threats have increased and diversified. It is not possible to solve the new security challenges with the old methods. Nation states are not able to overcome new threats because of the trans boundary 
Değișen Güvenlik Anlayıșının

Uluslararası Örgüt Örnekleri Üzerinden Analiz Edilmesi

nature of them. Therefore, the collaboration method should be preferred; international organizations and civil initiatives are to be activated. If human security can be established; a comprehensive and global security may also be ensured. Feminist theorists accept that it is a necessity to make fundamental revisions in existing security perceptions and applications to ensure the global security. On the other hand, critical approach emphasizes that individuals need to be liberated. According to them, reduction of the role of the nation state in international system will serve to the purpose of ensuring comprehensive security.

NATO and UN are special international organizations because they have been accepted as important elements of the international system not only during the Cold War period, but also after the Cold War. The purpose of both organizations is to prevent the deterioration of the security situation and to reconstruct the corrupted security situation. Both organizations have also been revised according to changing conditions of post Cold War era. This may be clearly observed when the NATO's security strategy documents and institutional changes are examined. The UN has been one of the main proponents of the human security concept. By means of new units created within the organization, security studies are carried out in the fields of society, individuals, environment, and economy.

NATO and UN are two actors of international system, which have solved the problem of survival and increased their efficiency level in the new era by revising themselves. Transformation of these two organizations can be considered as one of the proofs, which indicate that security concept has changed. Even though proponents of traditional security concept contradict, the security concept has changed as a result of the systematic and perceptual changes. NATO's transformation from a joint defense organization to a collective security organization and UN's works in different areas of security support the claim of change.

141

Güvenlik Stratejileri

Y11: 13

Sayl: 25 
Özlem ÖZKÖSEDAĞ IÇIN

\section{KAYNAKÇA}

\section{Kitaplar}

ARI, Tayyar, Uluslararası Illişkiler Teorileri. Çatışma. Hegemonya, İşbirliği, Alfa, Bursa, 2002.

ARI, Tayyar, Uluslararası Illişkiler ve Dış Politika, 7. Baskı, MKM Yayınlar1, Bursa, 2008.

AYDIN, Mustafa ve EREKER, Fulya, Türkiye'de Güvenlik Algl, Politika, Yapı, 1. Bask1, İstanbul Bilgi Üniversitesi Yayınları, İstanbul, Kasim 2013.

BALTA PAKER, Evren, Küresel Güvenlik Kompleksi. Uluslararast Siyaset ve Güvenlik, Birinci Bask1, İletişim, İstanbul, 2012.

BİRDİ̧LI, Fikret, Soğuk Savaş Sonrası Dönemde Güvenlik Alanında Yaşanan Son Gelişmeler Ile Birlikte Teori ve Pratikte Uluslararası Güvenlik. Kavram, Teori, Uygulama, Seçkin, Ankara, Ocak 2014.

BOOTH, Ken, Dünya Güvenliği Kuramu, çev. Çağdaş Üngör , Birinci Bask1, Küre Yayınları, Ağustos 2012.

BREZEZINSKI, Zbigniew, Büyük Satranç Tahtast Amerika'nın Küresel Üstünlüğ̈̈ ve Bunun Jeostratejik Gereklilikleri, çev. Yelda

\section{2}

Security Strategies

Year: 13

Issue: 25

\section{Türedi, İnkılâp Kitapevi, İstanbul, 2005.}

BURTON, John W., "International Relations or World Society", Paul R. Viotti and Mark V. Kauppi, (ed.), International Relations Theory: Realism, Pluralism, Globalism, 2. ed., Macmillan Publishing Co.

BUZAN, Barry, People, States and Fear: An Agenda for International Security Studies in the Post Cold War Period, Brighton, Harvester Wheatsheaf, 1991.

BUZAN Barry, WAEVER Ole and WILDE De Jaap, Security: A New Framework for Analysis, Lynne Rienner Publishers, London, 1998.

CANBOLAT, İbrahim S., Uluslararası İlişkilerde Türkiye Savaş ve Barış Arasında Dünya, 4. Bask1, Aktüel, Bursa, Kasım 2012.

CARR, E. H. Yirmi Yıl Krizi 1919-1939, Can Cemgil (çev.), 2. Bask1, İstanbul Bilgi Üniversitesi Yayınları, Ekim 2015.

DEDEOĞLU, Beril, Uluslararası Güvenlik ve Strateji, 3. Baskı, Yeni Yüzy1l, İstanbul, 2014.

HELD, David, Democracy and The Global Order From The Modern State to Cosmopoliten Governance, Polity Press, 1995. 
Değișen Güvenlik Anlayıșının

Uluslararası Örgüt Örnekleri Üzerinden Analiz Edilmesi

HOBBES, Thomas, Leviathan, der. C. B. Macpherson, Harmondsworth, Penguin, 1986.

KARABULUT, Bilal, Güvenlik. Küreselleșme Sürecinde Güvenliği Yenide Düsüunmek, Barıș Kitap, Ankara, 2011.

KRAUSE, Keith and WILLIAMS, Michael C., "From Strategy to Security:Foundations of Critical Security Studies", Keith Krause and Michael C. Williams (ed.), Critical Security Studies: Concepts and Cases, UCL Press, UK, 1997.

MORGENTHOU, Hans J., Politics Among Nations, The Struggle For Power and Peace, MC Graw Hill Higher Education, Seventh Edition.

MEARSHIMER, John J., The Tragedy of Greta Power Politics, W. W. Norton, New York, 2001.

NYE, Joseph S., Understanding International Conflicts. An Introduction to Theory and History, Longman, USA, 2003.

STEANS, Jill, PETTIORD, Lloyd, DIEZ, Thomas and EL-ANIS, Imad, Introduction to International Relations Perspectives and Themes, 3rd Edition, Routledge, 1999.

TERIFF,Terry, CROFT, Stuart, JAMES, Lucy and MORGAN, Patrick M., Security Studies Today, USA Polity Press, 1999.

Makaleler

ATAMAN, Muhittin, "Feminist Yaklaşımlar ve Uluslararası İlişkiler Teorileri", Tayyar Arı (der.) Uluslararası Ilişskilerde Postmodern Analizler 1. Kimlik Kültür Güvenlik ve Dış Politika, MKM Yayınları, Nisan 2012.

AYDIN Mustafa, "Uluslararası İlişkilerde Teori, Yaklaşım ve Analiz", Siyasal Bilgiler Fakültesi Dergisi, Cilt 50, No. 3-4, 1996.

AYDIN, Mustafa, "Uluslararası İlişkilerin "Gerçekçi" Teorisi: Kökeni, Kapsamı, Kritiği”, Uluslararası İlişkiler, Cilt 1, Sayı 1, Bahar 2004.

BAHARÇIÇEK, Abdulkadir, "Soğuk Savaşın Anlamı ve Sona Ermesinin Türk D1ş Politikası Üzerindeki Etkileri", İdris Bal (der.), 21. Yüzyılın Eşiğinde Türk Dış Politikası, 1. Baskı, Alfa Basım Yayım Dağıtım, Bursa, 2001.

BALDWIN, David A., "The Concept of Security", Review of International Studies, 1997.

143

Güvenlik Stratejileri

Y11: 13

Sayl: 25 
Özlem ÖZKÖSEDAĞ IÇiN

BAYLIS, John, "Uluslararas1 İlişkilerde Güvenlik Kavramı", Uluslararası Ilişskiler, Cilt 5, Say1 18, Yaz 2008, pp. 69-85.

BERENSKOETTER, Felix Sebastian, "Mapping the Mind Gap: A Comparison of US and European Security Strategies", Security Dialogue, Vol. 36, No. 1, March 2005, pp. 75-90.

BILlGiN, P1nar, "Individual and Societal Dimensions of Security", International Studies Review, Vol. 5, No. 2, Jun. 2003.

BOOTH, Ken, "Security and Emancipation", Rewiev of International Studies, Vol. 17, No. 4, Oct. 1991, pp. 313-326.

BOOTH, Ken, "Security and Self: Reflections of a Fallen Realist", Keith Krause and Micheal C. Williams (ed.), Critical Security Studies: Concepts and Cases, UCL Press, UK, 1997.

BRAUCH, Hans Günter, "Güvenliğin Yeniden Kavramsallaştırılması: Barış, Güvenlik, Kalkınma ve Çevre Kavramsal Dörtlüsü", Uluslararası İlişkiler, Cilt 5, Say1 18, Yaz 2008.

BLANCHARD, Eric M., "Gender, International Relations and the Developments of Feminist Security Theory", Chicago Journals, Vol 28, No. 4, Summer 2003.

144

Security Strategies Year: 13 Issue: 25

ERGÜL, Nihal, "Yeni Güvenlik Anlayışı Kapsamında Birleşmiş Milletler'in Rolü ve Uygulamaları", Atilla Sandıklı (ed.), Teoriler Işı̆̆ı̆nda Güvenlik, Savaș, Barıș ve Çatışma Çözümleri, Bilgesam Yayınlar1, İstanbul, 2012.

HERZ, John H., "Idealist Internationalism and Security Dilemma", World Politics, Cilt. 2, No. 2, 1950.

HEURLIN, Bertel and KRISTENSEN, Kristian, "International Security", International Relations, Vol. 2.

ERSOY, Eyüp, "Realizm", Ramazan Gözen (der.), Uluslararası Iilişkiler Teorileri, İletişim Yayınları, 1. Baskı, İstanbul, 2014. GIBSON, Ian, "Human Security: A Framework for Peace Constructs, Gendered Perspectives and Cosmopolitan Security", Journal of Peace, Conflict and Development, Issue 17, August 2011.

GRAY, Colin S., "The 21st Century Security Environment and the Future of War", Parameters, Winter 2008-2009. 
Değișen Güvenlik Anlayıșının

Uluslararası Örgüt Örnekleri Üzerinden Analiz Edilmesi

KRAHMANN, Elke, "Security Governance and Networks: New Theoretical Perspectives in Transatlantic Security", Cambridge Review of International Affairs, Vol 18, Num. 1, April 2005.

MEARSHIMER, John J., "Back to the Future: Instability in Europe after the Cold War", International Security, Vol. 15, No. 1, Summer 1990.

MILLER, Benjamin, "The Concept of Security: Should It Be Redefined?", Journal of Strategic Studies, Vol. 24, Issue. 2, 2001.

MUTIMER, David, "Reimagining Security: The Metophors of Proliferation", Keith Karuse and Michael C. Williams (ed.), Critical Security Studies:Concepts and Cases, UCL Press, UK, 1997.

OĞUZLU, H. Tark, "Dünya Düzenleri ve Güvenlik: Ulus-Devlet Güvenlik Anlayışı Aşılıyor mu?", Güvenlik Stratejileri Dergisi, Sayı 06, 2007.

OVALI, A. Şevket, "Ütopya İle Pratik Arasında: Uluslararası İlişkilerde İnsan Güvenliği Kavramsallaştırması", Uluslararası Ilişkiler, Cilt 3, Say1 10, Yaz 2006.

ÖZLÜK, Erdem ve ÖZLÜK, Duygu, “NATO’yu Anlamak: Dönüşümü, Yeni Kimlikleri ve Uyum Süreçleri”, Selçuk Üniversitesi Sosyal Bilimler Enstitüsï Dergisi, Say1. 31, 2014.

ROTHSCHILD, Emma, "What Is Security?", Daedalus, Vol. 124, No.

3, The Quest for World Order, Summer 1995.

SOLONA, Javier, "NATO's Success in Kosovo", Foreign Affairs, Vol. 78, No. 6, November/December 1999.

TANGÖR, Burak, "Kuramsal Tartışmalar Işığında İnsan Güvenliği ve Politikaları", Uluslararası Hukuk ve Politika, Cilt 8, Sayı 30, 2012.

Güvenlik Stratejileri

Y11: 13

Sayl: 25

ULLMAN, Richard H., "Redefining Security", International Security, Vol. 8, No. 1, Summer 1983.

WAEVER, Ole, "Toplumsal Güvenliğin Değişen Gündemi", Uluslararası İlişkiler, Cilt 5, Sayı 18, Yaz 2008.

WALT, Stephen M., "The Renaissance of Security Studies", International Studies Quarterly, Vol. 35, No. 2, Jun. 1991.

WALTZ, Kenneth N., "Anarchic Orders and Balances Of Power", Robert O. Keohane (der.), Neorealism and Its Critics, Columbia University Press, New York, 1986. 


\section{Özlem ÖZKÖSEDAĞ IÇCiN}

WALTZ, Kenneth N., "The Origins of War in Neorealist Theory", Journal of Interdisciplinary History, Vol. 18, No. 4, The Origin and Prevention of Major Wars, Spring 1988.

WOLFERS, Arnold, "National Security: As an Ambiguous Symbol", Political Science Quarterly, Vol. 67, No. 4, December 1952.

İnternet Kaynakları, Kurumların Raporları, Kararları ve Strateji Dokümanları

Alliance's Strategic Concept, Approved by the Heads of State and Government participating in the meeting of the North Atlantic Council in Washington D.C., Issued on 23-24 April 1999, NATO Web Sitesi: http://www.nato.int/docu/pr/1999/p99-065e.htm, Erişim tarihi: 01.05.2015.

ANNAN, Kofi, "Towards a Culture of Peace", Seçen, Federico Mayor-Roger-Pol Droit, Letters to Future Generations, UNESCO Publishing, http://unesdoc.unesco.org/images/0011/001185/118573E.pdf, Erişiom tarihi: 15.02 .2015

ANNAN, Kofi, We the peoples: The Role of the United Nations in the 21th Century, http://www.un.org/en/events/pastevents/ pdfs/We The Peoples.pdf, Erişim tarihi: 5.10.2015 for Europe, A Paper Prepared for the Maastricht Forum on the Future of Europe, Maastricht University Press, Earth Charter International, Hollanda 9-11 May 2007.

BM Kurucu Antlaşması 51. Madde, https://treaties.un.org/doc/ publication/ctc/uncharter.pdf, Erişim Tarihi: 06.04.2015.

Commission on Human Security, Human Security Now, UN Publications, New York, 2003.

Conclusions and Plan of Action of the Extraordinary European Council Meeting, 21.09.2001, http://eu-un.europa.eu/articles/en/ article_153_en.htm, Erişim tarihi: 20.02.2015.

Declaration of the Heads of State and Government, 29 May 1989, http://www.nato.int/cps/en/natohq/official_texts_23554.htm?selectedL ocale=en, Erişim tarihi: 02.05.2015. 
Değișen Güvenlik Anlayıșının

Uluslararası Örgüt Örnekleri Üzerinden Analiz Edilmesi

Declaration on a Transformed North Atlantic Alliance "The London Declaration", 05-06 July 1989, http://www.nato.int/cps/en/natohq/ official texts_23693.htm?selectedLocale=en, Erişim tarihi: 02.05.2015.

Human Security Report 2005, http://www.hsrgroup.org/humansecurity-reports/2005/text.aspx, Erişim tarihi: 02.01.2015.

Istanbul Summit Communiqué, 28 June 2004, http://www.nato.int/ docu/pr/2004/p04-096e.htm, Erişim tarihi: 03.05.2015.

LYNN-JONES, Sean M., International Security Studies after the Cold War: An Agenda for the Future. CSIA Discussion Paper 91-11, Kennedy School of Government, Harvard University, December 1991. http://live.belfercenter.org/files/disc_paper_91_11.pdf., Erişim tarihi: 02.03.2015.

NATO's Core Security Functions in the New Europe, 06-07 Jun.1991, Press Rlease M-1(91) 44 44, http://www.nato.int /cps/en/natohq/official_texts_23861.htm?selectedLocale=en, Erişim tarihi:02.05.2015,

MCKAY, Susan, "Women, Human Security, and Peace-building: A Feminist Analysis", Conflict and Human Security: A Search for New Approaches of Peace-building (2004), IPSHU English Research Report Series No. 19.

Report of the Secretary-General (1992), An Agenda for Peace Preventive diplomacy, peacemaking and peace-keeping, A/47/277 S/24111 17 June 1992, http://www.unrol.org/files/A_47_277.pdf, Erişim tarihi: 10.09.2015.

Repertoire of the Practice of the Security Council, Decision of 31 January 1992 (3046th meeting): statement by the President, http://www.un.org/en/sc/repertoire/89-92/Chapter\%208/GENERAL\%2 OISSUES/Item\%2028_SC\%20respons\%20in\%20maint\%20IPS.pdf, Erişim tarihi:10.09.2015.

ROBERTSON, George (Lord Robertson of Port Ellen), Kosova One Year On. Achievement and Challenge, http://www.nato.int/ kosovo/repo2000/report-en.pdf, Erişim tarihi:10.05.2015.

SADHWANI, Gouri, The Hague Appeal for Peace Conference, http://www.mediate.com/articles/hague.cfm, Erişim tarihi:11.09.2014.

147

Güvenlik Stratejileri

Y11: 13

Sayl: 25 


\section{Özlem ÖZKÖSEDAĞ IÇCiN}

Strategic Concept for the Defence and Security of the Members of the North Atlantic Treaty Organisation Adopted by Heads of State and Government in Lisbon, 10 Nov 2010, http://www.nato.int/cps/en/ natohq/official_texts_68580.htm?selectedLocale=en, Erişim Tarihi: 01.09.2015.

UNDP, Human Development Report 1994, Oxford University Press, New York, 1994, http://hdr.undp.org/sites/default/files/reports/255/hdr_1994_en_comple te_nostats.pdf., Erişim tarihi: 15.12.2014.

http://www.eolss.net/sample-chapters/c14/E1-35-04-02.pdf, Erişim tarihi: 25.02.2015.

http://www.undp.org/content/undp/en/home/mdgoverview/, Erişim tarihi: 01.09.2015.

http://www.unodc.org/unodc/en/about-unodc/index.html?ref=menutop, Erişim tarihi: 01.09.2015.

http://www.unwomen.org/en/about-us/about-un-women, Erişim tarihi: 01.09.2015.

http://unhabitat.org/about-us/history-mandate-role-in-the-un-system/, Erişim tarihi: 02.09.2015.

Strategies http://www.unhcr.org/pages/49c3646cbc.html, Erişim tarihi: 02.09.2015. 